\title{
CLAY MINERALOGY OF THE SEDIMENTARY ROCKS OF THE PARANÁ BASIN, BRAZIL*
}

\author{
ADRIANO N. RAMOS** and MILTON L. L. FORMOSO***
}

ABSTRACT The clay mineral composition of 1,052 core samples from 43 wells drilled in the eastern and southern parts of the Paleozoic Paraná Basin have been investigated by X-ray diffractometry. The clay mineral suites are characterized by a mixture of illite, chlorite, mixed-layer illite-montmorillonite, which are the dominant minerals, with subordinate amounts of kaolinite, montmorillonite and mixed-layer chlorite-montmorillonite. Most of the clay minerals are detrital but, at least, some of the illite, kaolinite, and corrensite have been diagenetically formed. Illite and chlorite are found throughout the section. Mixed-layer illite-montmorillonite are well developed in the Permian Rio Bonito and Palermo Formations, becoming rarer in older formations due to diagenesis or climatic conditions. Kaolinite occurs in the continental Devonian Furnas Formation and in the deltaic, and nearshore facies of the Rio Bonito Formation. Smectites are important in some formations of the Rio Grande do Sul and São Paulo States and in the upper part of stratigraphic column, as a result of different regional sedimentary or volcanic source areas and/or climatic conditions. Corrensite generally occurs associated with the oolitic limestones of the Permian Teresina Formation, suggesting diagenetic processes in marine environment. Such minerals as expansive chlorite and irregular mixed-layer chlorite-montmorillonite suggest different stages of alteration of chlorite and magnesian chlorite suggests diagenesis. Hydrocarbon shows in the Paraná Basin have been reported especially in the Rio Bonito Formation, and are thought to be related to the greater abundance of expansive clay minerals.

RESUMO Foram estudadas 1052 amostras de testemunhos de 43 poços da parte leste e sul da Bacia do Paraná com a finalidade de definir os argilominerais presentes na coluna estratigráfica. Ilita, clorita e interestratificados ilita-montmorilonita são os argilominerais dominantes, refletindo, em sua maior parte, o caráter eminentemente detrítico da sedimentação. Ilita e clorita ocorrem em toda a seção. Os interestratificados ilita-montmorilonita são muito característicos nas formações Rio Bonito e Palermo. Nas formações subjacentes tornam-se raros por condições diagenéticas ou climáticas. A caulinita é pouco freqüente. Aparece na Formação Furnas e nas fácies consideradas deltaicas da Formação Rio Bonito. A montmorilonita (esmectita) é importante na parte superior da coluna estratigráfica, principalmente na Formação Botucatu e topo do Grupo Rio do Rasto, e em algumas formações no Rio Grande do Sul e em São Paulo, representando aporte de áreas fontes diferentes e/ou condições climáticas que não permitiram alteração avançada. A presença da corrensita, associada em geral aos calcários oolíticos da Formação Teresina, é muito característica, sugerindo processos diagenéticos em ambiente marinho. Clorita expansiva e interestratificados irregulares clorita-montmorilonita sugerem diferentes graus de alteração da clorita, enquanto clorita magnesiana sugere diagênese. Acredita-se que os numerosos indícios de hidrocarbonetos registrados na Formação Rio Bonito estejam relacionados com a maior abundância de minerais interestratificados ilita-montmorilonita.

*Part of the data included in this paper has been presented by one of the authors at the XXVIII Congresso Brasileiro de Geologia, 1974, Porto Alegre

**Departamento de Exploração e Produção (DEXPRO), Petróleo Brasileiro S.A. (PETROBRÁS), Rio de Janeiro, RJ

***Instituto de Geociências da Universidade Federal do Rio Grande do Sul e CIENTEC, Porto Alegre, RS 
INTRODUCTION This report presents the results of the investigation by X-ray diffractometry led by the authors at the laboratories of the Instituto de Geociencias da Universidade Federal do Rio Grande do Sul, in order to study the clay mineral suites of 824 core samples from wells drilled by Petróleo Brasileiro S.A. - Petrobrás - in Paraná Basin, Southern Brazil. The data previously obtained by one of the authors (Ramos, 1970a) from the study of another 228 samples at the laboratories of the Centre de Sedimentologie et Géochimie de la Surface, Université de Strasbourg, France, are also included in this report. Other investigations, concerning partially the clay mineral X-ray diffractometry of Paraná samples, have been presented by Neves (1973) and SNPA (1973).

The main purposes of this work were (a) to verify the lateral and vertical distribution of the clay mineral suites, in order to obtain additional informations for reconstructing the depositional environment and geologic history of the different lithostratigraphic units of the Basin, and (b) to verify the post-lithification alterations which could have influenced the original sedimentary sequence.

Although no particular clay mineral suite can be ascertained to a specific environment of deposition (Millot, 1952; Weaver, 1958), the investigation of these minerals has contributed to the study of depositional environment, origin and direction of transport of sediments, tectonic conditions, diagenesis, paleogeographic reconstruction, stratigraphic cor* relation, and in searching for oil and other mineral resources (Parham, 1966; Weaver, 1960). Post-lithification alterations of clay minerals, modifying the original composition, have been recognized by several authors and are summarized by Millot (1964) and Grim (1968). However, it is thought that these mineral suites reflect, at least in part, the clay mineral assemblages of the originally deposited sediments (Smoot, 1960b).

Area of study The Parana Basin is a large intracratonic Paleozoic basin with an area of approximately $1,200,000 \mathrm{~km}^{2}$ only in the Brazilian portion. Fig. 1 shows the generalized map of the studied area and the location of the wells drilled by Petrobras in the eastern and southwestern parts of the Basin.

Three distinct regions can be considered in the area, according to the paleostructural behavior and to the influence of the regional structures in the sedimentation (Ramos, 1970b). The first one comprises the State of São Paulo and the northern part of the Paraná State, northward from the Ponta Grossa Arch. The second one covers all the remaining eastern portions, including the main part of the Parana State, all the wells drilled in Santa Catarina State and in the northeastern portion of the Rio Grande do Sul State. Finally, the third one is situated in the southwestern part of the State of Rio Grande do Sul southward from the Rio Grande Arch, where only three wells have been drilled.

Methods of work SAMPLE PREPARATION The analytical method employed was the X-ray diffractometry. The samples were gently crushed, disaggregated and mixed with water until the particles were dispersed. The less than 2-micron fraction was separated by sedimentation and used to prepare 2 or 3 oriented slides for each sample. The slides thus obtained were successivelly investigated under the X-ray diffractometer, first in untreated form, then after glycolation and, separately, after heating to $490^{\circ} \mathrm{C}$, according to the method described by Lucas, Camez, and Millot (1959).

X-RAY IDENTIFICATION The parameters employed at the Philips Norelco X-ray diffractometer of the Instituto de Geociencias of UFRGS were: goniometer speed $2^{\circ}(2 \theta)$ per minute, constants dependable on the intensity of the clay mineral reflections, $\mathrm{Cu}$ tube $(35 \mathrm{kV}, 20 \mathrm{~m} \mathrm{~A})$ with $\mathrm{Ni}$ filter. In analyzing well cores for stratigraphical purposes, it is 


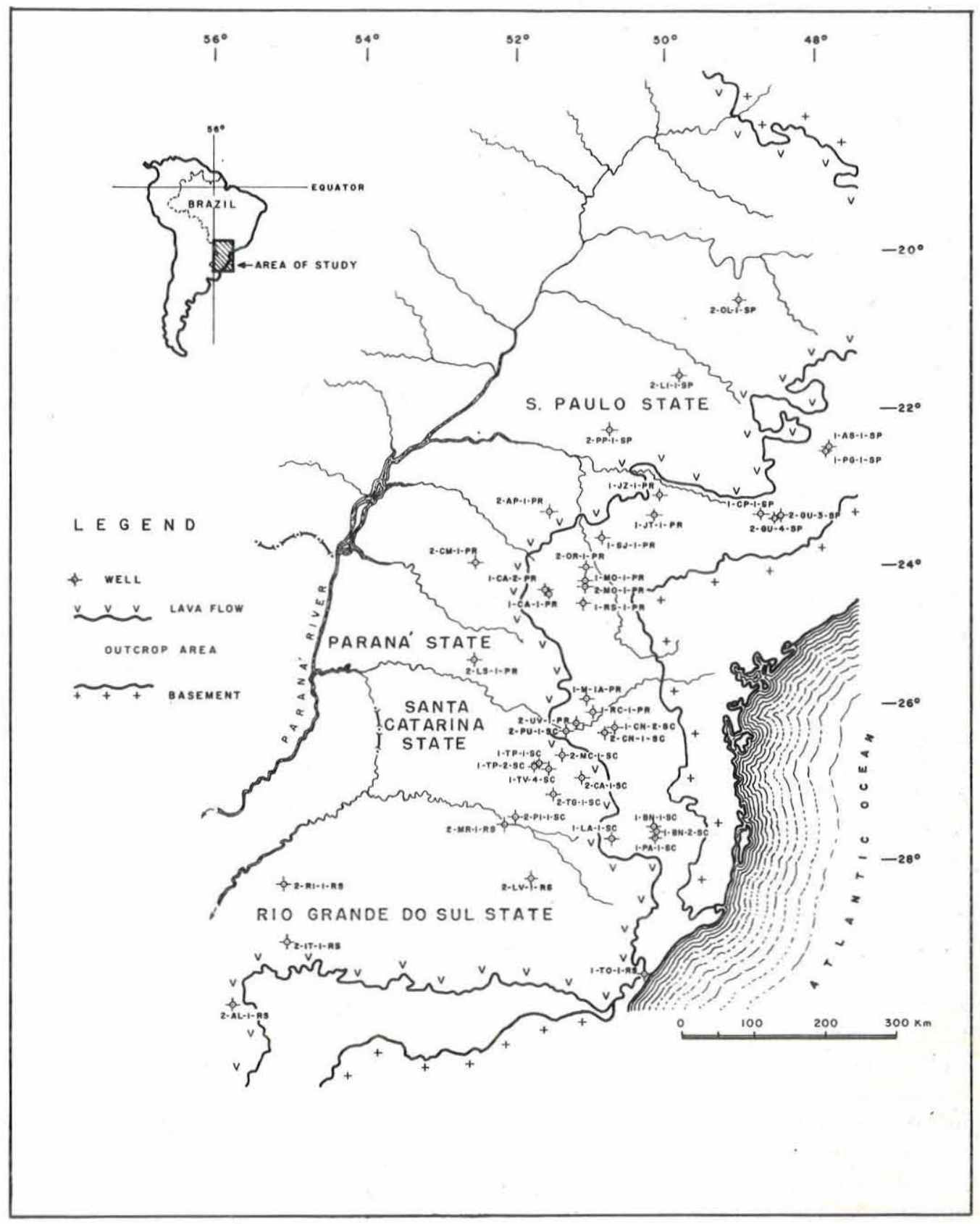

Figure 1 - Generalized map of Paraná Basin, showing location of wells

only necessary to identify the groups of clay minerals: kaolinites, smectites (montmorillonites), illites, chlorites, and the mixed-layer clay minerals, both regular or irregular. Detailed studies of the source areas, environments of sedimentation, stratigraphic correlation and others, will require further specific determinations.

Each clay mineral group is identified by its X-ray diffraction characteristics. Illites are recognized by basal reflections at $10 \AA, 5 \AA$, and $3.3 \AA$, unchanged by glycolation or 
heating. Chlorites are identified by peaks at $14 \AA, 7 \AA, 4.7 \AA$, and $3.5 \AA$. Most chlorites of the Parana Basin samples have a low reflection at $14 \AA$, and the $7 \AA$ and $3.5 \AA$ peaks are partly or completely destroyed after heating while the $14 \AA$ peak is either preserved or increased. Kaolinites are defined by basal reflections at $7 \AA$ and $3.5 \AA$. Distinction between chlorite and kaolinites has not always been made by the $14 \AA$ and $4.7 \AA$ reflections, because iron-rich chlorites have low intensity peaks at those positions. After heating to $490^{\circ} \mathrm{C}$, the $7 \AA$ peak of kaolinite disappears (Lucas, and Jehl, 1961), but the same may happen to chlorite peaks due to partial destruction of brucitic layers. Thus, distinction between kaolinite and chlorite was made from the double peak at $3: 5 \AA$ reflection according to the method proposed by Bradley (1954); kaolinite has a second-order (002) reflection at approximately $3: 58 \AA$ and chlorite has a fourth order (004) one at approximately $3.51 \AA$. Smectites generally present basal reflections at a $14-15 \AA$ period (more rarely at $12 \AA$ ), expanding to $17 \AA$ by glycolation, and collapsing to $10 \AA$ after heating. Mixed-layer clay minerals are constituted by an association of simple structural units of different clay minerals. Mixed-layers can be either of a regular type, showing multiple spacing and well defined peaks reflecting a structural periodicity, or of an irregular one, exhibiting broad, undefined shoulder reflections without any ordered arrangement. Mixed-layer illite-montmorillonite are the most common in the Paraná Basin samples. They can be represented by just degraded illite - illite ouverte - with a $10 \AA$ peak slightly asymmetrical toward lower angles; mixed-layers associated with illite, in which the non-expansive layers persist at $10 \AA$ but some portions expand by glycolation; and, finally, true mixed-layer illite-montmorillonite exhibiting a peak between $10 \AA$ and $14 \AA$, usually around $11 \AA$, which is divided, after glycolation, into two peaks, one shifted toward lower angles and another toward higher angles in regard to the untreated peak samples. Mixed-layer chlorite-montmorillonite are also of several types and may be abundant in Paraná samples. Slightly degraded chlorites - chlorite gonflante - expand by glycolation but return to $14 \AA$ after heating. Irregular mixed-layer chlorite-montmorillonite are a second type in which chlorite generally predominates, expanding toward lower angles by glycolation and shifting to higher angles after heating. A third type is a regular mixed-layer chlorite-montmorillonite, denominated corrensite, exhibiting well defined spacings. First-order peak (001) appears at $29 \AA$, expanding toward $31 \AA$ by glycolation and shifting to $24 \AA$ after heating; second-order (002) appears at $14-15 \AA$ and fourth order (004) at $7.2 \AA$ in untreated samples.

SEMIQUANTITATIVE DETERMINATION Quantitative calculations of clay minerals by diffraction methods are dependable upon such factors as type of matrix, clay mineral composition, sample preparation, cristallinity, and others. Semiquantitative determination has been described by Johns, Grim, and Bradley (1954), Formoso (1963), and Weaver (1967). Brindley (in Brown, 1961) discusses the possibilities and limitations of the quantitative or semiquantitative methods. However, semiquantitative data are very valuable in studying lateral or vertical changes in sedimentary clay mineral assemblages, especially in well sections, where the variations are more important than the absolute values in delineating the geographic range and maximum development of a particular mineral (Parham, 1966).

The semiquantitative method employed by the authors is used at the laboratory of the Centre de Sédimentologie et de Géochimie de la Surface, Strasbourg University, France. According to this method, the calculations are done by measuring the peak intensity of illite at $10 \AA$, half the peak intensity of kaolinite at $7 \AA$, and the peak intensity of montmorillonite at $14 \AA$ or $15 \AA$ in untreated samples. The intensity of chlorite is measured at the height at $8.8^{\circ}(2 \theta)$ of an immaginary line connecting the peaks of $14 \AA$ and $7 \AA$. The inten- 
sities of mixed-layer clay minerals are measured at the point of maximum height of the peak or area. The measured intensities are further compared and the results are expressed in parts per ten. For data presentation, the estimated values of mixed-layer illite-montmorillonite have been plotted separately from the illite, regardless of whether they are individually recorded in the X-ray diffractions or not.

The degree of diagenesis was estimated using the method proposed by Kubler (1964). The width of illite peak $(10 \AA)$ is measured at half way the base and the highest point of the peak. This process is based on the transformation of mixed-layer clay minerals to illite stricto sensu under diagenetic conditions, reflected in the X-ray diffractions by increasing sharpness of the $10 \AA$ peak. Weaver (1960) measures the ratio between the height of the peak at $10 \AA$ and at $10.5 \AA$, which becomes larger as approaching the metamorphism zone.

Sedimentation and clay minerals in Parana Basin GENERAL DISCUSSION The sedimentation in Paraná Basin is essentially detrital. The mineral suites depend largely on the source area conditions. Climate is an important factor upon the preservation or destruction of some minerals less resistant to weathering (Milne and Earley, 1958). Topographic and tectonic conditions, acting on the source areas, exert their influence on the maturity of the transported minerals, included the clay minerals.

Millot (1964) discusses the role played by climate and tectonics upon the sedimentation. The deposited materials are either originated directly by erosion from the continental rocks, or from the soils, where they undergo more or less deep alterations. Continents in emergence or high relief lands supply great quantities of erosion products to the area of accumulation, reflected in the coarser facies and nature of the sediments. The character of the sedimentation is dominantly detrital. Conversely, low relief lands or source areas far from the depositional basin supply mainly weathering products and finer grained sediments; the minerals become more and more degraded, and the detrital sedimentation gradually gives way to the chemical one. On the other hand, cold, periglacial climates, and arid climates inhibit both the development of vegetation and the alteration of the materials in the soils - if they are scarcely formed - and, in consequence, the sediments result directly from the continental rocks. Humid, tropical or equatorial climates, instead, are favorable for the formation of highly vegetated areas and well developed soils, where some minerals are degraded and others are neoformed. In addition, tectonic and climatic conditions may vary and change with time, and may interfere into one another. The nature of the alterations and the intensity of erosion result from the equilibrium between those conditions. Furtherly, diagenetic processes will imprint their characteristics upon the inherited materials.

In the Parana Basin, the major source area is considered to be the Brazilian Shield or rocks originated from it. Obviously, in such a tremendous area, different regional source terranes and different climatic conditions must be expected throughout, and, thus, sediment contributions may vary from a region to another. Nothwithstanding, the predominance of illite and chlorite seems to be justifiable. Illites are the most abundant clay minerals. They are derived from acidic igneousmmetamorphic continental source rocks or sediments derived from them. They are normally detrital, although some illites, like glauconite and iron-illites may be neoformed (Jung, 1954). Most chlorites are also detrital in origin, contributed from the crystalline source rocks. Weathering tends to alter the brucitic layer by loss of magnesium and iron oxidation (Brindley and Ali, 1950), and some recrystallization may occur in marine waters under diagenetic effects. Mixed-layer illite-montmorillonite are believed to be due to alteration of illites under weathering climates in the source areas. In the lower part of the stratigraphic column these mixed-layers are 
rare or absent, suggesting that climatic and tectonic or diagenetic processes are major controlling factor in the predominance of illite. In the Furnas and Ponta Grossa Formations, diagenesis must be responsible for the relative lack of mixed-layer illite-montmorillonite. In the Itarare Group this could be attributed to a detrital origin, controlled in the source area by a cold climate and/or high relief, intense erosion and fast burial. In the Rio Bonito Formation, the mixed-layer illite-montmorillonite are the most important and characteristic clay minerals, reflecting the amelioration of the climatic conditions, which enabled development of luxuriant vegetation in relatively low land areas.

Kaolinite and montmorillonite, typical weathering products, are rare in the stratigraphic column. Kaolinite occurs mainly in the terrestrial Furnas Formation and in the deltaic, nearshore areas of the Rio Bonito Formation. In these latter areas, it has been observed a general decrease in abundance of kaolinite towards the center of the basin. In other formations, kaolinite occurs only locally, and its persistence has not been verified vertically or laterally. Montmorillonite occurs mainly in the upper part of the sedimentary column, and in some formations in the Rio Grande do Sul and São Paulo States, reflecting, in this case, particular contributions from regional source areas.

Mixed-layer chlorite-montmorillonite are also present, and some deserve a special reference. Corrensite, a regular interstratification of chlorite-montmorillonite, generally occurs associated with the widespread oolitic limestones of Teresina Formation, suggesting the presence of particular conditions of depositional environment and occurrence of diagenetic processes. Corrensite occurs also in other formations and associated with other lithologies, but in localized occurrences. On other hand, irregular mixed-layer chlorite-montmorillonite are also present, due to weathering of chlorite. Expansive chlorites and magnesian-chlorites were also recorded, but not so characteristically as corrensite.

Summarizing, the predominance of detrital over chemical sedimentation was, in general, reflected in the clay mineral assemblages by an abundance of illite and chlorite. Some of the other clay minerals present in the geologic column may be helpful in interpreting the original composition and post-depositional changes, either degradational or aggradational as well as diagenetic processes acting on the sediments.

Stratigraphy The stratigraphic column proposed by Sanford and Lange (1960) - to whom the reader is referred - was adopted in this work, particularly for the Paraná and Santa Catarina States, with slight modifications. In some wells of the Rio Grande do Sul State, it was adopted the column proposed by Damiani Pinto et al. (1966). So, it was used the division of the so-called Passa Dois Group, that comprises the Irati, Estrada Nova and Rio do Rasto Formations. The Santa Maria and Botucatu Formations were not individualized. In some São Paulo wells, the denomination of Corumbatal Formation was maintained to designate the section between the Irati and Botucatu Formations. Also in this case, the Botucatu and Piramboia Formations were not separated from one another. For the sediments of the Guata Group, when possible, it was used the Rio Bonito-Palermo division proposed by Thomaz and Medeiros (1972), corresponding in the São Paulo State to what had been previously called Itapetininga Formation, divided into two members, Tupi and Tatui (Barbosa, and Gomes, 1958).

There is no agreement in the literature among the major authors regarding to the establishment of a standard stratigraphic column for all the Paraná Basin, neither in relation to the nomenclature adopted nor about the description of the lithostratigraphic units, and divergent views are far from being harmonized. However, the discussion of these concepts is not under the scope of the present work and cannot be considered here. 
Recently, Schneider et al. (1974) have presented a stratigraphical revision of the Paraná Basin.

The clay mineral composition of the Alegrete well (Rio Grande do Sul State), Tangará well (Santa Catarina State), Joaquim Távora well (Paraná State), and Olímpia well (São Paulo State) are shown in Figs. 3 to 6 to give the reader a general idea of the geologic column, unit names and lithologies for each geographical area. Lithologic and clay mineral symbols used in the well logs are illustrated in Fig. 2.

\section{I T H OL O G Y}
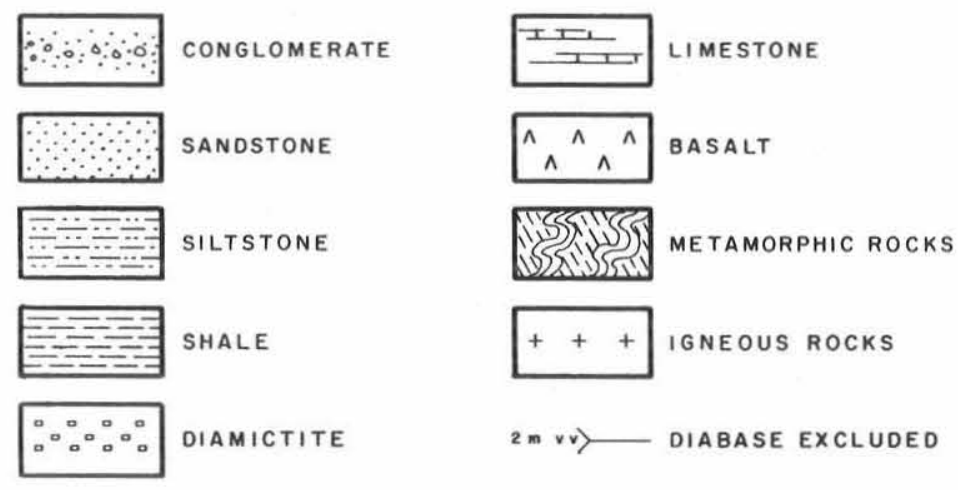

\section{CLAY MINERALOGY}

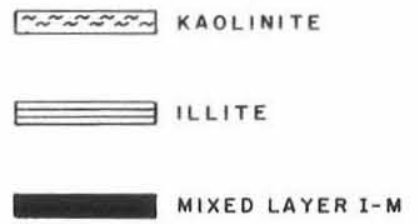

[IIIIIIIIIIIII) CHLORITE

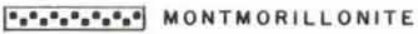

$\% \% \%$ CORRENSITE

Figure 2 - Lithologic and clay mineral symbols used in Figs. 3 to 6

CLAY MINERALS OF THE FURNAS FORMATION This formation is represented by 20 core samples from 10 wells. Most of the samples came from wells drilled in the Paraná State. The dominant lithology consists of medium to coarse, white to light gray, quartzose sandstones, with conglomeratic horizons, with clayey matrix, frequently silicified in subsurface, afossiliferous and characteristically cross-stratified - mainly through cross-stratification associated with tabular cross-stratification-throughout the section. The maximum thickness in the area under study is greater than $300 \mathrm{~m}$. Different interpretations concerning the environment of deposition have been formulated by several authors. Recently, Ludwig and Ramos (1965) attributed to this formation a deposition in continental-fluvial environment. The clay mineral data agree, in a general way, with this assumption. 


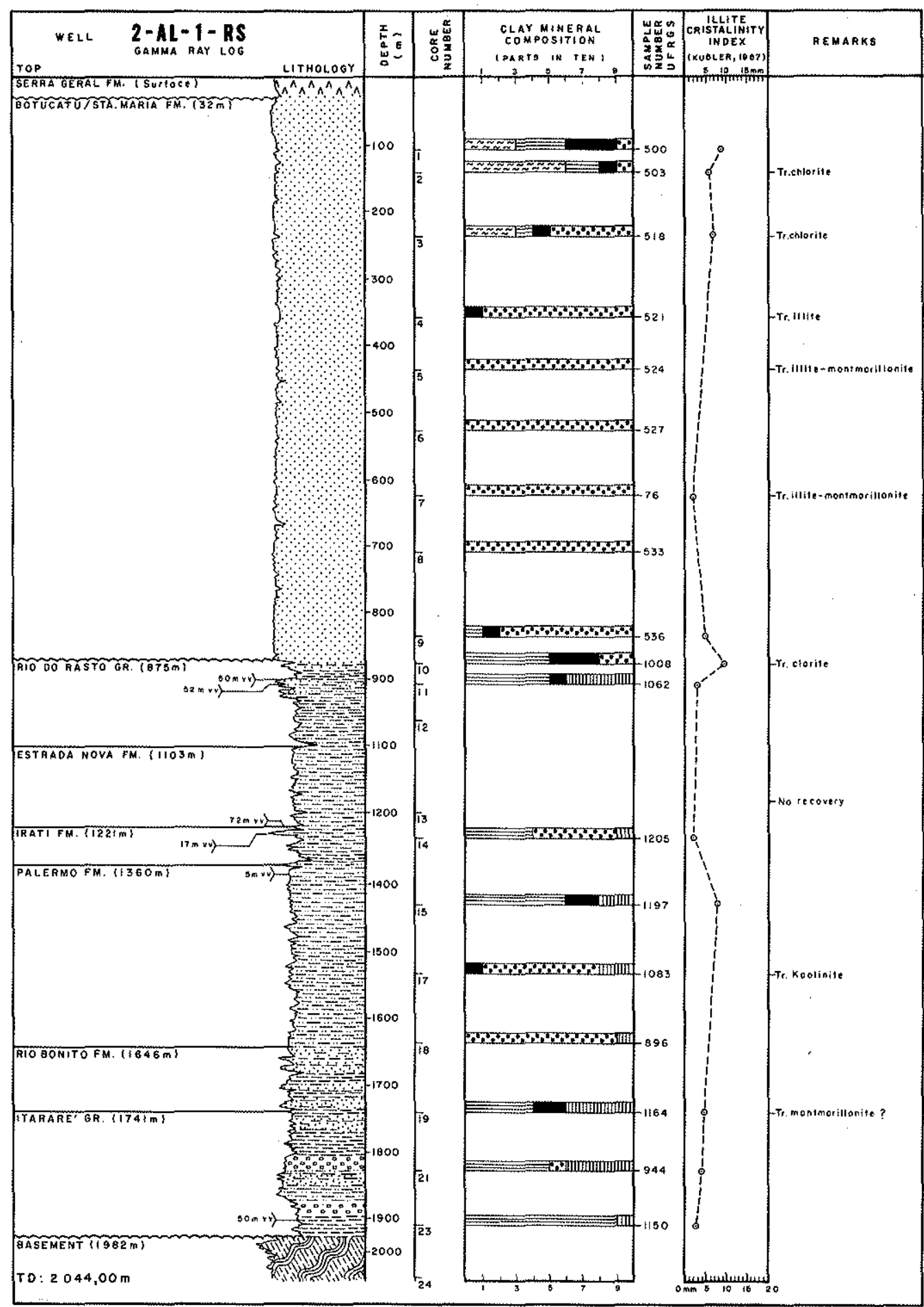

Figure 3 - Clay mineral composition of 2-AL-1-RS (Alegrete, Rio Grande do Sul) well 


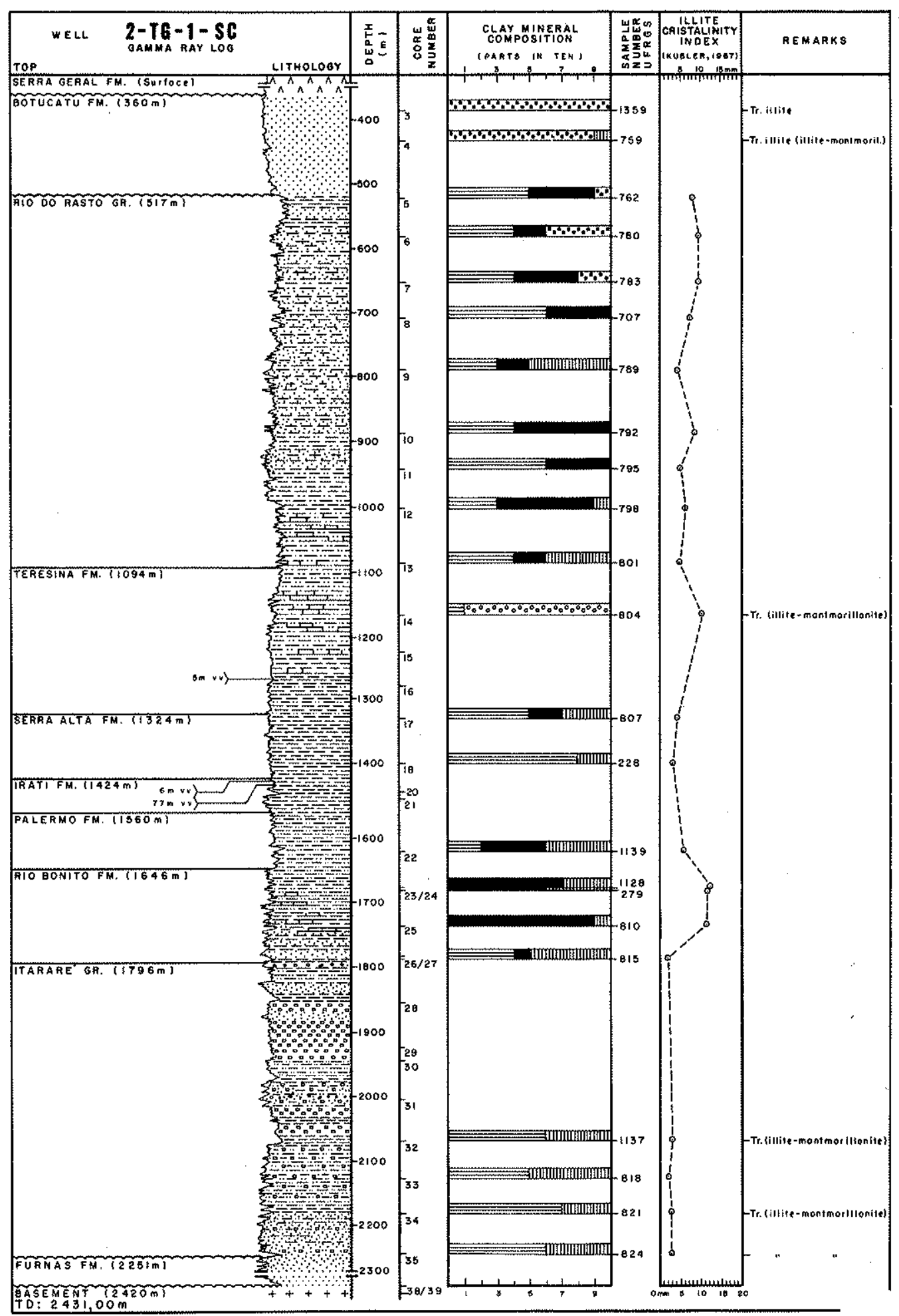

Figure 4 - Clay mineral composition of 2-TGm1-SC (Tangará, Santa Catarina State) well 


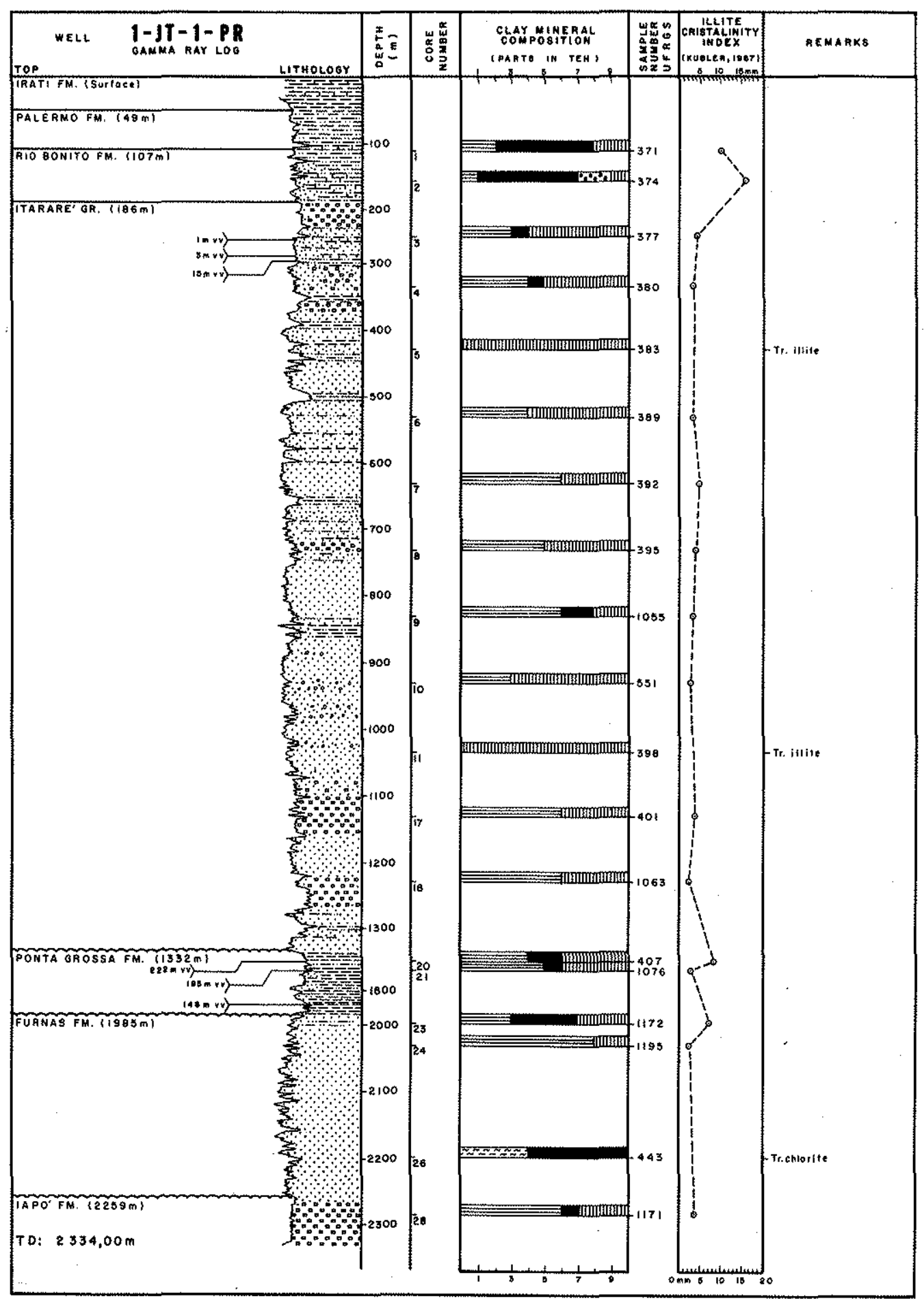

Figure 5 - Glay mineral composition of 1-JT-I-PR (Joaquim Távora, Paraná State) well 


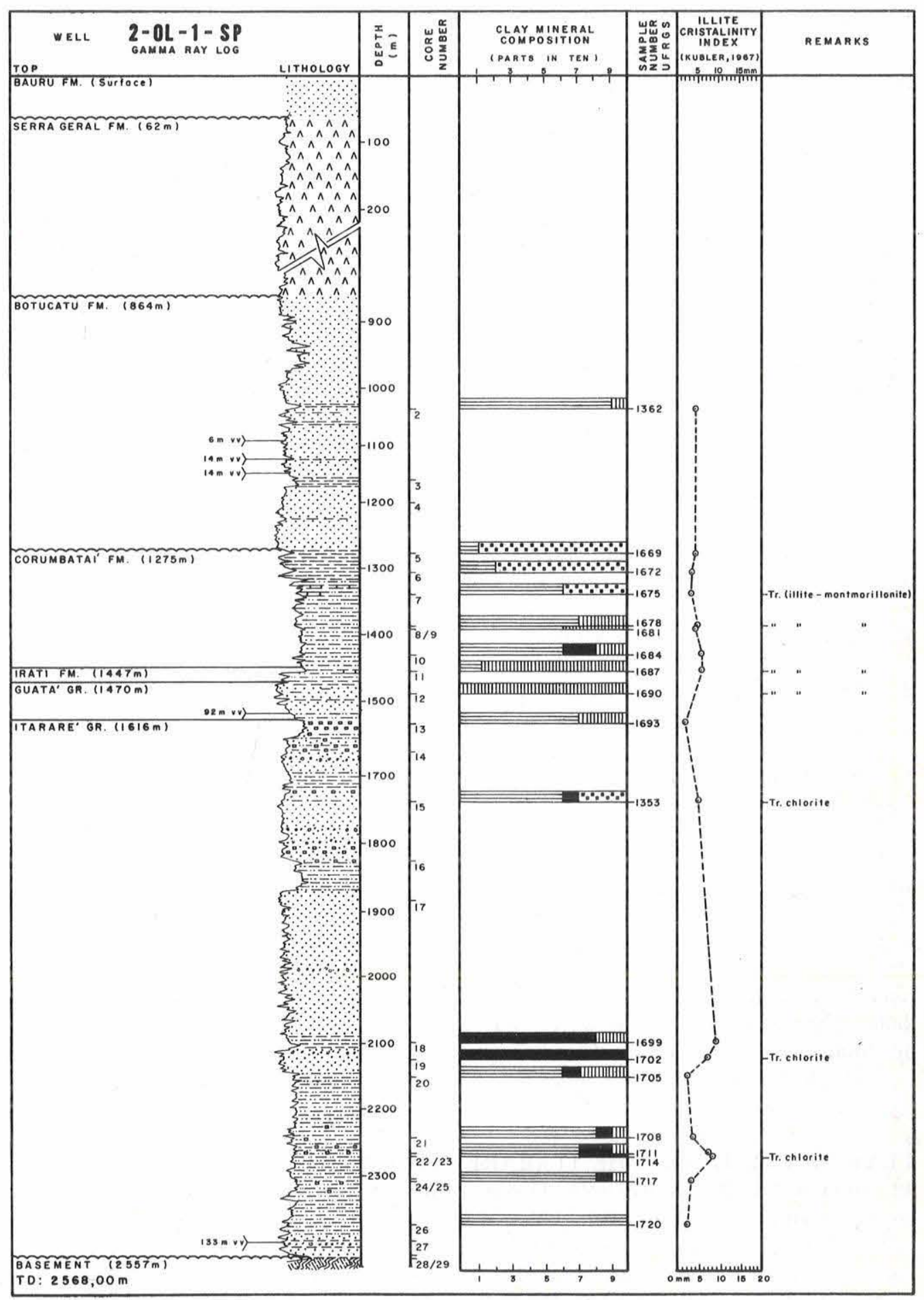

Figure 6 - Clay mineral composition of 2-OL-1-SP (Olímpia, São Paulo State) well 
The clay minerals are illite, predominant in most of the samples, kaolinite, chlorite and mixed-layer illite-montmorillonite. Eight samples contain kaolinite. Among other minerals, quartz is highly abundant. Muscovite is common. Pyrophyllite was reported in two samples.

Dominance of quartz, presence of kaolinite and lack of feldspar and other less stable minerals, suggest a mineralogical maturity. Unstable minerals must have been destroyed in the source area. The predominance of illite among the clay minerals, apparently contradictory, could be interpreted as originated by diagenetic processes. The Kubler's index of the illites is in general very low, meaning an accentuated cristallinity. The (002) reflexion $(5 \AA)$ is intense, and the ratio $(002) /(001)$ is high, suggestive of alluminous illites of good cristallinity (Esquevin, 1969). The $10 \AA$ peak sharpness could be related to (a) immaturity of the sediment (short transport); (b) cold climate with low weathering; and (c) diagenesis. The first two possibilities can be eliminated by the lack of unstable minerals and the presence of kaolinite. In the authors' opinion, mixed-layer illite-montmorillonite and kaolinite have been diagenetically transformed, at least partly, into illite. Pyrophyllite could also be indicative of diagenetic processes. The possibility of it being of detrital origin is remote, because it does not occur sistematically and the alluminous mineral sedimentary assemblage would point to a diagenetic formation.

CLAY MINERALS OF THE PONTA GROSSA FORMATION 75 core samples from the Ponta Grossa Formation came from 18 wells. 66 samples are from wells located in the Parana State, 7 in the northern Santa Catarina State, and only 2 in southwestern São Paulo State. Gray to black micaceous, laminated shales are the dominant lithology, with some intercalations of siltstones and fine sandstones mainly in the upper and lower parts of the section. From the great fossiliferous record, environment of deposition is known to be marine. The sediments were probably deposited in widespread shallow epicontinental seas. Greatest thickness is $653 \mathrm{~m}$ recorded in the Apucarana well (2-AP-1-PR).

Among the clay minerals, illite is highly dominant. Chlorite and mixed-layer illite-montmorillonite are subordinate. Kaolinite is rare.

In the Apucarana well, the more argillaceous facies in the middle part of the formation, from 3,400 to $3,700 \mathrm{~m}$ deep, are richer in mixed-layer clay minerals than the more arenaceous lower and upper ones. It is suggested that, in the coarser grained sections; mixed-layers have been diagenetically transformed into illite by circulating fluids, while in the finer grained section, because of the lower permeabilities, the clay mineral suites have been less altered and represent more closely the original composition. Weaver (1967) reports illite and mixed-layer illite-montmorillonite in equal proportions in marine black shales. The above observations suggest that transformation of mixed-layers into illite would be a diagenetic process rather than an aggradation by simple contact with the sea waters.

The Kubler's index of the illites is low, denoting a tendency to recrystallization. Pyrophyllite is present in one sample, suggesting diagenetic effects.

CLAY MINERALS OF THE ITARARE GROUP 333 samples were studied from 42 rather widely distributed wells. Dominant lithologies are diamictites, sandstones and conglomerates, intercalated with shales, rhytmites and varved shales. Coal is known to occur in the upper part of the group in São Paulo State. Environment of deposition of the entire group was very variable and is believed to range from continental glacial, fluvioglacial, glaciomarine to marine (Northflęet, Medeiros, and Muhlmann, 1969). Certain layers contain marine fossils. In the studied area, the greatest thicknesses are recorded in the São Paulo depositional basin, with a drilling maximum of $1,281 \mathrm{~m}$. Thickness decreases 
southward and the group may be absent in the easternmost portion of the Rio Grande do Sul State.

Illite and chlorite, the characteristic association of the group, largely predominate among the clay minerals. Illites are dioctahedric, alluminous and the chlorites are, in general, of an iron rich type with low (001) and (003) reflections. A few chlorites are magne* sian or expansive. Kaolinite is very rare. Montmorillonite occurs only in some areas, especially in São Paulo and western part of the Rio Grande do Sul State. Mixed-layers are characteristically scarce. Fig. 7 shows the X-ray diffraction patterns of the characteristic association illite-chlorite.

The clay mineral data agree, in a general way, with an environmental interpretation based on a high-relief source area dominated by cold climate. Crystalline rocks in the source area should liberate well crystallized illite and chlorite in the finer fraction. Feldspars and quartz are commonly present. Cold climate and/or high relief areas would be res-

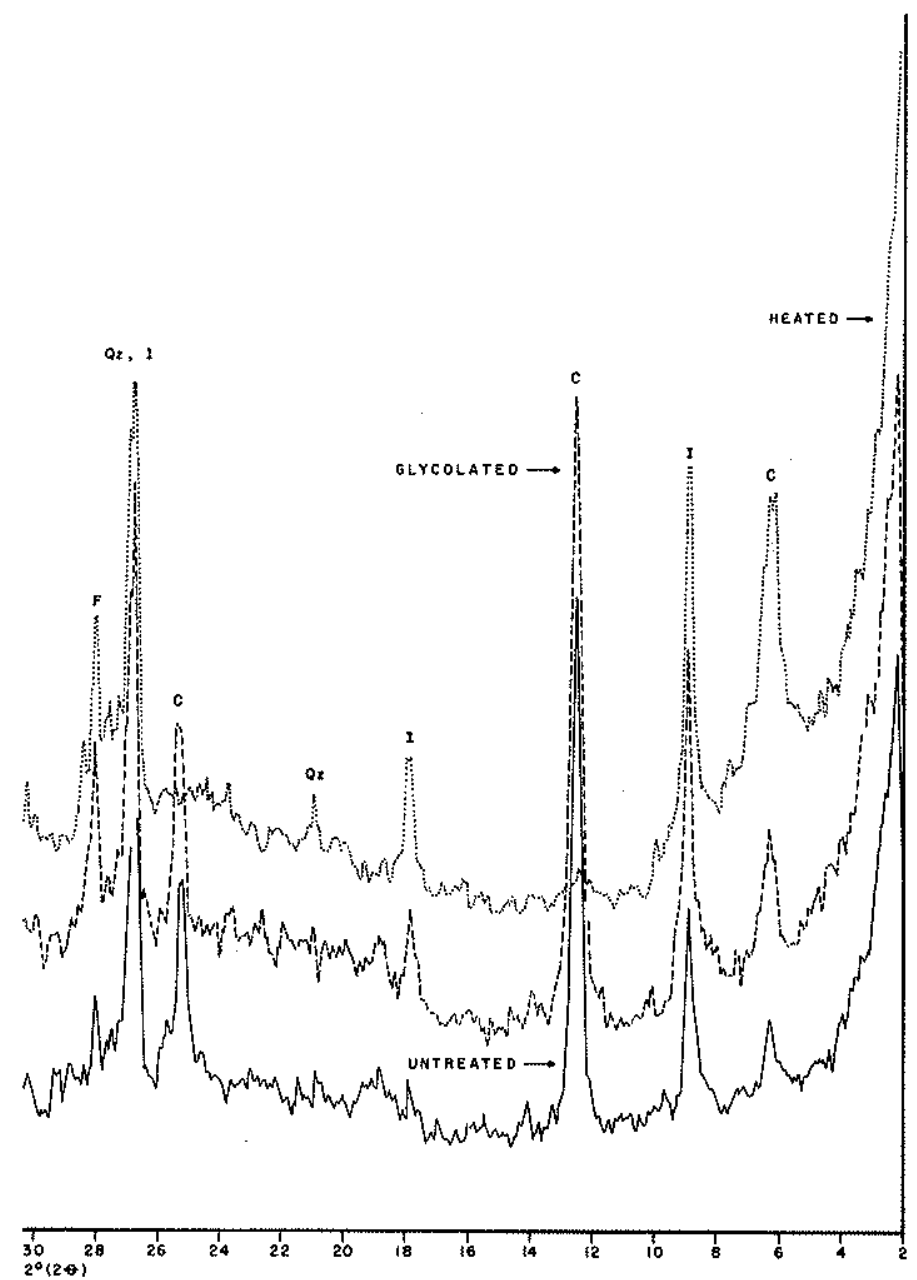

Figure 7 - X-ray diffraction curves of sample 1304 , core 35, depth 2,344,25 m Itararé group, 1-TP-2-SC well, illustrating illite $(\mathrm{I})$ and chlorite $(\mathrm{C})$ patterns. Quartz $(\mathrm{Qz})$ and feldspar $(\mathrm{F})$ are also present 
ponsible for an intense disaggregation of the continental rocks and erosion would be greater than weathering processes. So, detrital materials, little or not degraded in the source areas, would be rapidily transported and buried, and relatively well crystallized clay minerals would likely to be preserved in the depositional areas. These processes would be reflected not only in the mineralogical sedimentary composition but also in the coarser clastic nature-including frequent cobbles and boulders-of the sediments supplied to the areas of accumulation, both continental or marine. No significant clay mineral variations were observed with different lithologies. The association illite-chlorite is the same throughout the basin, even in thickest sections. Differences in apport from local source areas should account for the presence of montmorillonite in the distal parts of the studied area. Kaolinite and mixed-layer illite-montmorillonite, showing an increase in degradational changes, are found in the upper part of the group in the Parana and Santa Catarina areas. This would already mean a more temperate and humid climate besides relatively lower land masses.

Kubler's index values are lower than those of the underlying Ponta Grossa Formation, from which the group is separated by a large unconformity. It seems likely that diagenesis was not a strong factor in the present clay mineral composition of the Itarare Group. Minerals like pyrophyllite were not observed, although some indication of diagenetic effects could be inferred from the presence in some samples of magnesian chlorite. And, of course, the possibility of some of illite being diagenetic can not be excluded.

CLAY MINERALS OF THE RIO BONITO FORMATION 285 core samples from 33 wells drilled in the Paraná, Santa Catarina, and Rio Grande do Sul were examined. Lithologically, the formation consists of fine to medium sandstones, with some coarse bodies, intercalated with shales and siltstones. Irregular beds of argillaceous limestones occur in the middle part of the formation. Locally, there are coal beds. The formation is rich in plant fragments, pollen and spores, and marine fossils are known from some beds. The greatest thickness reported in the eastern part of the basin is in the Lajes well (1-LA-1-SC) with $286 \mathrm{~m}$. For the southeastern flank of the basin, Ramos (1967) interpreted eastward continental, deltaic and interdeltaic deposits passing through transitional, nearshore tidal flat sediments to more marine conditions westward. Provenance was believed to be from the east. Some transgressions and regressions recognized in the section make the general picture quite complex.

Among the clay minerals, mixed-layer illite-montmorillonite are highly dominant and characteristic of the formation. Kaolinite, montmorillonite, chlorite, and illite are the other clay minerals. The mixed-layers appear under several types. The most common one is represented by a broad peak near $11 \AA$ which by glycolation bifurcates at approximately $10 \AA$ and $12 \AA$. These diffractions patterns were observed both in well cores and in outcrop. Fig. 8 illustrates the typical curves of mixed-layer illite-montmórillonite. In association with illite, the $(001)$ peak remains at $10 \AA$, but is asymmetrical towards lower angles and this portion expands by glycolation. Illite separated from the mixed-layer illite-montmorillonite occurs less commonly, and even more rare is the presence of just degraded illite (illite ouverte).

Kaolinite occurs characteristically in certain areas of the Rio Bonito Formation. In general, it is mainly detrital in origin, but some may be recrystallized or neoformed. It is very common in coal basin in the Rio Grande do Sul State. Formoso and Figueiredo F. (1966), and Formoso (1966) have described in that State the association illite-montmorillonite/kaolinite. The present core sample study has revealed that the areas prior considered to be deltaic [Lajes, Petrolândia, and Barra Nova (SG), and Rio Claro, and Mallet (PR)] with thicknesses from 200 to $300 \mathrm{~m}$, are richer in kaolinite, which is sometimes the 


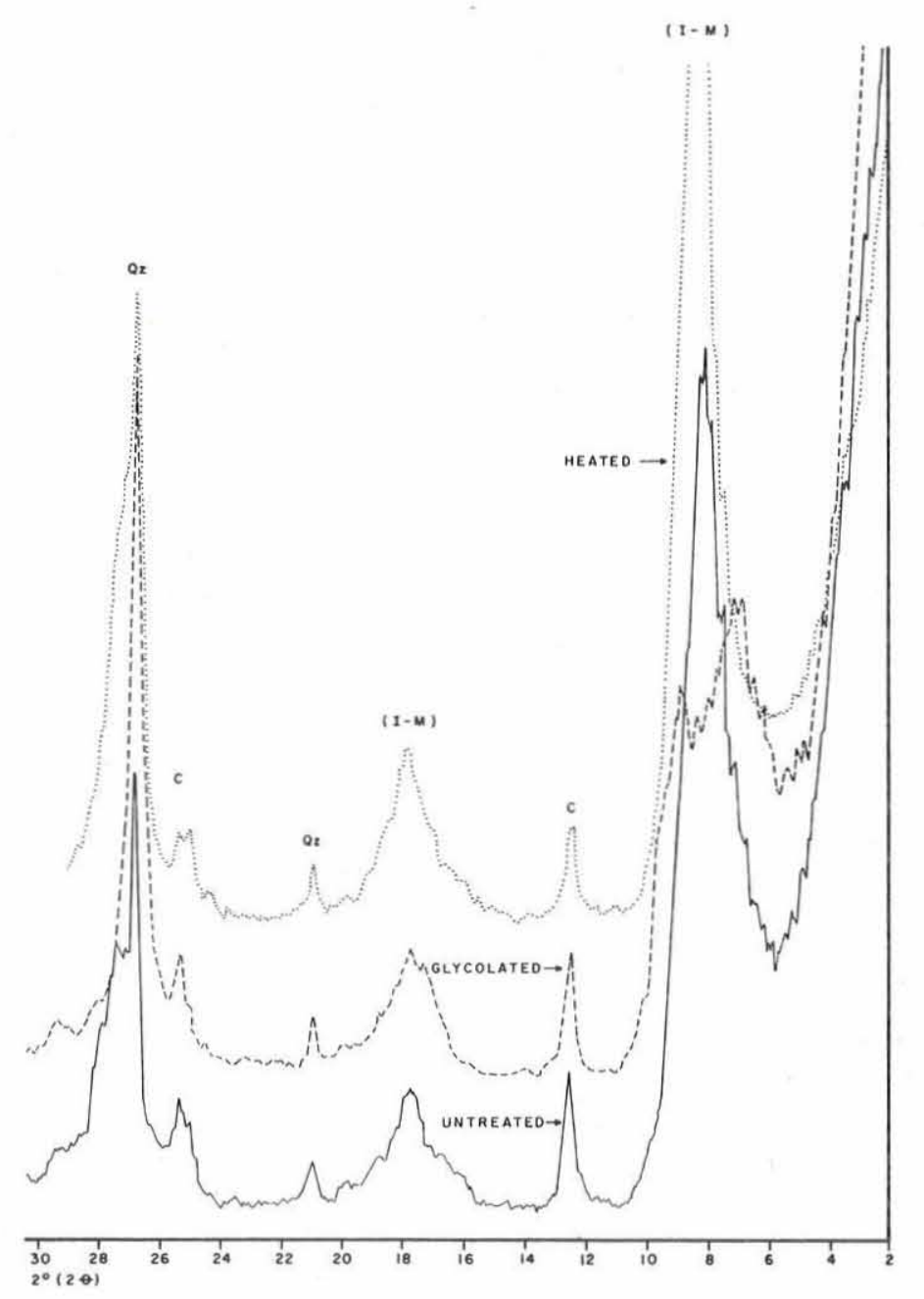

Figure 8 - X-ray diffraction curves of sample 482, core 22, depth 403,0 m, Rio Bonito Formation, 1-BN-1-SC well, illustrating typical curves of mixed-layer illite-montmorillonite (I-M). Quartz $(\mathrm{Qz})$ and chlorite $(\mathrm{C})$ are also present

dominant clay mineral. In other areas, such as Lagoa Vermelha, Torres, and Itacurubi (RS) kaolinite is a common mineral. In Torres, it occurs associated with coal beds. Kaolinite decreases westward, that is, from the facies considered to be terrestrial and nearshore to those marine. This agrees with the data from Parham (1964), Shover (1964), Pryor, and Glass (1961), Griffin, and Ingram (1955) among others, who report similar situations, i.e., kaolinite is more abundant in fluvial environment and in rocks deposited nearshore, and less common in offshore sediments, both in recent or ancient sediments. Montmorillonite is rare in the studied samples. Where present, it should reflect local source areas. Chlorite does not show any significant variation.

Millot (1964) considers that kaolinite is formed on the continents under humid, warm climates, characterizing intense alteration in acidic, well leached environment. It would also be formed in peat and coal beds, where humic matters do percolate. In paludal environments, partial decomposition of organic matter and the associated acidity would lead 
to post-depositional changes towards the neoformation of kaolinite or to its diagenetic recrystallization, as in the tonsteins. Formoso (private communication) identified vermicular kaolinite in claystone beds associated with coal seams in the Candiota coal basin, and Correia da Silva (1973) described, in the same basin, an in situ recrystallization or neoformation of kaolinite, microscopically identified by its peculiar accordeon aspect.

As we have already seen, unweathering, cold climates and high relief source areas prevailed during most of the sedimentation of the Itarare Group, changing gradually to the more temperate, humid climates of the Rio Bonito depositional times. These facts, associated with highly vegetated lowland masses or more distant sources, should have enabled important alteration processes in the source area materials, forming, by degradation, mixed-layer illite-montmorillonite of several types, and kaolinite. Non-degraded illite is rare and the preservation of mixed-layers and kaolinite at great depths seems likely to indicate that diagenesis was not a very strong factor in determining the present clay mineral composition. By other hand, Kossovskaya and Shutov (1970) relate that diagenetic processes can also be interrupted by the presence even insignificant of hydrocarbons, which are common is this formation.

Two aspects are important in this formation as compared with underlying rocks. In the first place, the Kubler's index has very high values, showing the higher degradation of changes introduced in the materials by weathering processes at the source area. Secondly, the amount of mixed-layer illite-montmorillonite increases toward the upper part of the formation, independently of lithology or geographic position relative to the depositional basin. Mineralogical composition does not change appreciably whether the formation lies directly over the basement or the Itarare rocks.

CLAY MINERALS OF THE PALERMO FORMATION 49 samples from 30 wells were analyzed in this study. The formation consists mainly of gray to green shaly siltstones, commonly bioturbated, and minor fine sandstones. In the Santa Catarina and Paraná areas, normal thickness is around $90 \mathrm{~m}$. In the studied area, the greater thickness $-281 \mathrm{~m}$ - was recorded in the Alegrete well (2-AL-1-RS) in the western Rio Grande do Sul State. Deposition is attributed to a shallow nearshore marine environment, under very stable tectonic conditions (Northfleet, Medeiros, and Muhlmann, 1969).

Among the clay minerals, mixed-layer illite-montmorillonite are dominant, followed by illite and chlorite. Kaolinite is not abundant and occurs locally in the same areas as in the Rio Bonito Formation. Montmorillonite is abundant in the Alegrete well, and in the Leão-Butiá and Candiota outcrop areas in the Rio Grande do Sul State (Formoso and Figueiredo, 1966). In São Paulo, illite and chlorite are predominant instead of mixed-layer illite-montmorillonite. Almost pure montmorillonite was recorded in some samples in the Alegrete well, making possible to differentiate it from the smectites of overlying formations. Smectites in the Palermo Formation were identified as of an aluminous, dioctahedric type (Willig and Formoso, 1971).

As in the Rio Bonito Formation, mixed-layer illite-montmorillonite are the dominant clay minerals, suggesting that the altered lowland areas or soils continued to supply those minerals to the depositional basin. Aggradation to illite did not occur because of lack of favorable environmental conditions and/or diagenesis. True mixed-layers are common. Some have a tendency to regularity (allevardite), indicating an initial phase of diagenesis (Dunoyer de Segonzac, 1970).

CLAY MINERALS OF THE IRATI FORMATION This formation is represented in this study by 35 samples from 23 wells rather widely distributed. Lithologically, it con- 
sists dominantly of gray to black, bituminous to carbonaceous shales, with intercalations of limestone beds and chert concretions. Limestones are thicker and more frequent in the São Paulo State. In the Santa Catarina and Paraná areas, normal thickness varies around $50 \mathrm{~m}$. Greatest thickness - $96 \mathrm{~m}$ - is recorded in the Itacurubi well (2-IT-1-RS) in the western Rio Grande do Sul State. Depositional environment is believed to be shallow marine with restricted circulation. Fossils are teeth and fish scales, and reptilian remains, including the well known Mesosaurus brasiliensis.

Illite, mixed-layer illite-montmorillonite, and chlorite are the dominant minerals, independently of lithology. Mixed-layers are not so important as in the underlying Palermo and Rio Bonito Formations. Kaolinite is very rare or lacks completely. Montmorillonite occurs in the southern part of the basin and in the São Paulo State.

Formoso and Figueiredo F. ${ }^{\circ}$ (1971) and Delaney and Formoso (1960) have described pure montmorillonite beds in Biboca and São Gabriel, Rio Grande do Sul. In subsurface, some wells drilled in that State are almost exclusively made up of montmorillonite. A sample from the Torres well (2-TO-I-RS) is of a trictahedric magnesian smectite. Since other known occurrences have been desbribed as of alluminous, dioctahedric smectites, they should be investigated in detail to explain whether they result from different sources or from neoformation in the basin. Montmorillonite was not recorded in the samples from Santa Catarina wells. Corrensite was found in two wells. Expansive chlorite was also noted.

Absence of kaolinite in the Irati and overlying formations should mean either that the weathering climate prevailing in the underlying Rio Bonito and Palermo Formations became less humid with poorly drained soils or that source areas became more and more distant from the depositional basin. Illite would be preserved and contributed along with few mixed-layers. Diagenetic effects are inferred from the transformation of degraded chlorites into corrensite.

CLAY MINERALS OF THE SERRA ALTA FORMATION 36 samples from 23 wells correspond to this formation. Lithologically, it consists of fine grained sediments, mainly dark gray to black shales. Greatest thickness is $120 \mathrm{~m}$ found in the Matos Costa well (2-MC-1-SC). Environmental interpretation attributes to the formation a deposition in shallow marine waters (Northfleet, Medeiros, and Muhlmann, 1969).

Clay mineral assemblage is similar to that of the Irati Formation. Illite is slightly dominant over illite-montmorillonite and chlorite. True mixed-layer illite-montmorillonite like those of the Rio Bonito and Palermo Formations are rare. Kaolinite is also rare. Montmorillonite occurs locally. In the Petrolândia well (1-PA-1-SC) there is a thin, white lamina of pure montmorillonite inside dark gray shales containing two in ten parts of montmorillonite (Ramos, 1970a). Corrensite is rare, occurring in only one well.

CLAY MINERALS OF THE TERESINA FORMATION This formation is represented by 57 core samples from 23 wells. Commonest lithologies are gray to grayish green intercalated siltstones and shales, fine sandstones, lenses, and beds of oolitic limestones and chert. Primary structures include wavy stratification, flaser structure, mudcracks and micro-cross lamination. Depositional environment is assumed to be shallow marine with widespread agitated tidal flats, subjected to intermittent exposures (Northfleet, Medeiros, and Muhlmann, 1969). Fossils do not provide any reliable evidence concerning the environment of deposition, and this question is still highly debatable. In the studied area, greatest thickness was recorded in the Campos Mourão well (2-CM-1-PR) with 398 m. 


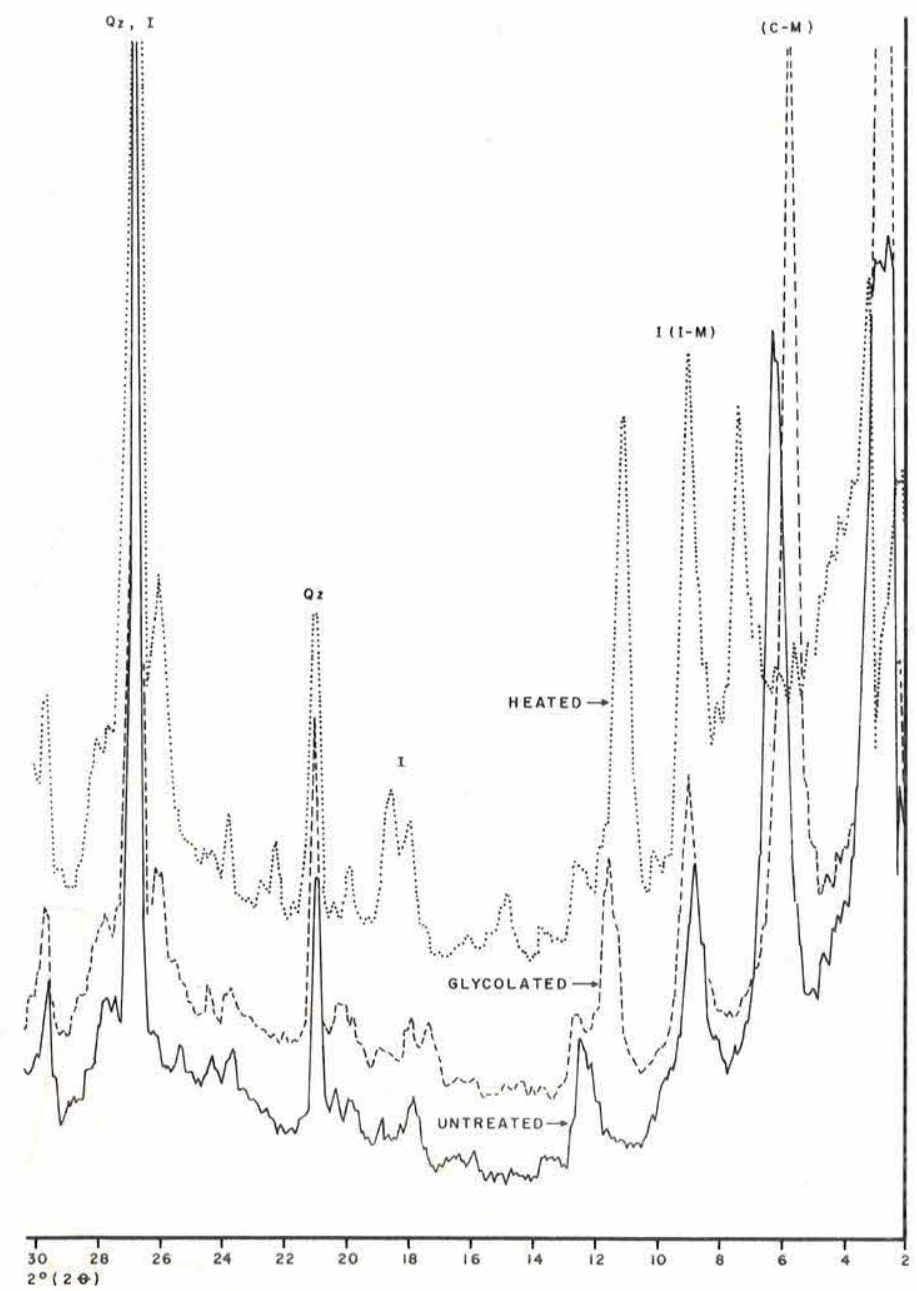

Figure 9 - X-ray diffractometer curves of sample 614, core 13, depth 1,162,2 m, Teresina Formation, 1-GA-1-SC well, illustrating regular mixed-layer chlorite-montmorillonite (C-M) patterns. Illite associated with mixed-layer illite-montmorillonite (I-M) and quartz $(\mathrm{Qz})$ and are also present

Illite, mixed-layer illite-montmorillonite, montmorillonite, and chlorite are common minerals. Corrensite is the characteristic mineral. In general, it is associated with the oolitic limestone zones. Corrensite is related to chlorite. Degraded or expansive chlorites are probably formed from chlorite due to surficial alterations in the source areas. The transition is from expansive through irregular mixed-layer chlorite-montmorillonite to regular interstratification or corrensite. Both types of interstratification are found in this formation. Fig. 9 illustrates the X-ray diffraction curves of corrensite. Reflections of corrensite and the clay mineral composition of associated minerals are shown in Table I.

Corrensite represents an aggradation in a magnesium rich environment, early in the sedimentation (Dunoyer de Segonzac, 1970). This aggradation continues during diagenesis and according to Kubler (1973) corrensite constitutes a diagenetic indicator. By its significance, it will be discussed in a separate chapter. Here, it suffices to say that a marine origin can be attributed to the oolitic limestones and associated sediments of this formation, as had been interpreted from other lines of evidence by some previous investigations. 
Table I - X-ray diffractions of corrensite and clay mineral composition of samples in which it occurs

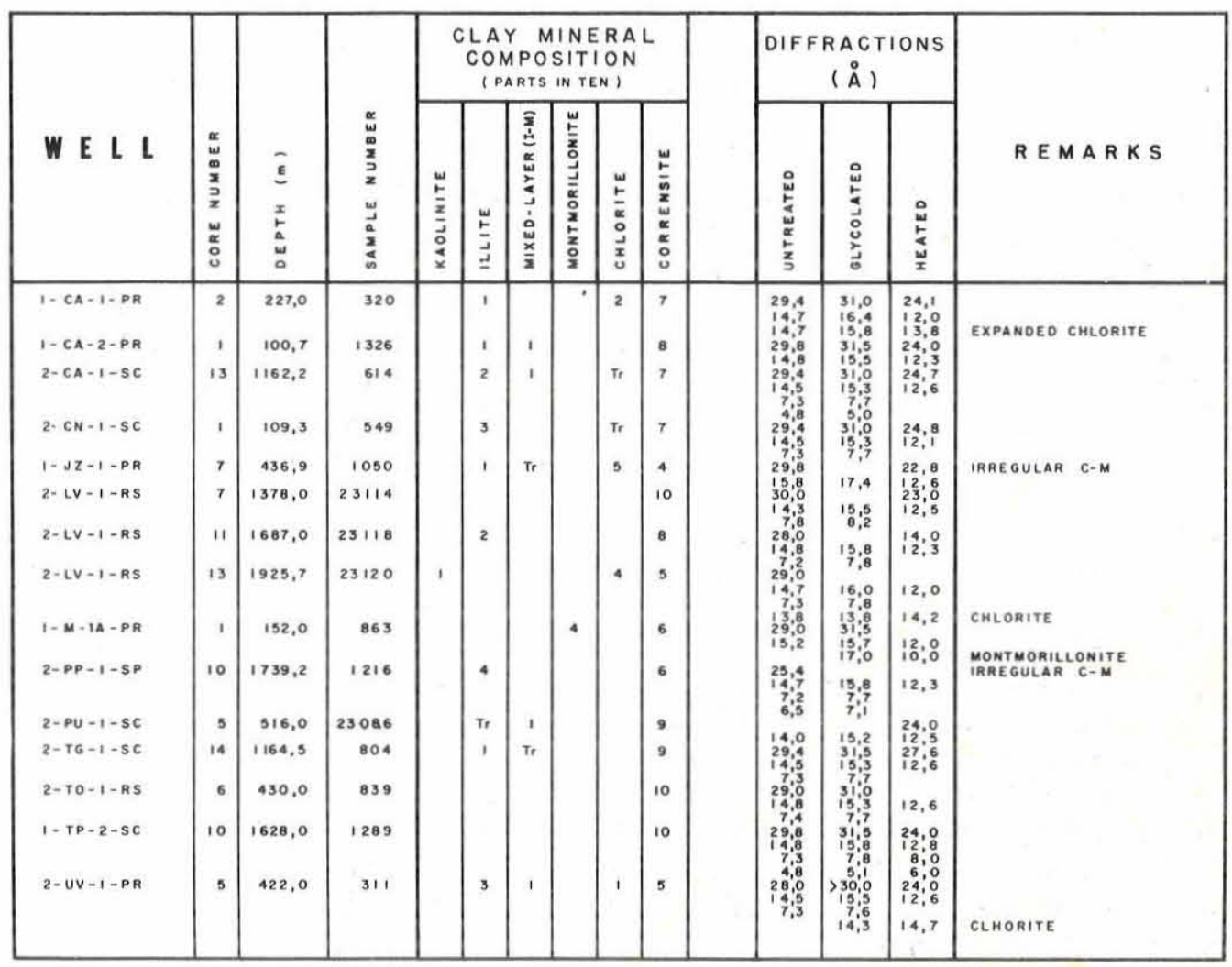

CLAY MINERALS OF THE CORUMBATAf FORMATION This formation is represented by 15 samples from 4 wells located in the São Paulo State. The formation is exclusive of that State. It has been differently stated by Sanford and Lange (1960) as equivalent to the upper Serra Alta and lower Teresina Formation in the Paraná State, while Schneider et al. (1974) consider one part of it as correlating with the Teresina and Serra Alta Formations, and another part with the Serrinha Formation of the Rio do Rasto Group.

Clay mineral assemblage includes montmorillonite, predominant over most of the samples, followed by illite, always present. Chlorite is subordinate. Mixed-layer illite-montmorillonite is rare. It is to be noted that montmorillonite and chlorite are mutually excludent, in the studied samples.

CLAY MINERALS OF THE ESTRADA NOVA FORMATION 7 samples from 2 wells drilled in the southwestern Rio Grande do Sul State illustrate this formation. In this area, the formation consists of green to red siltstones, with calcareous concretions, averaging $50 \mathrm{~m}$ thick; it is difficult to establish the contacts with the Irati and Rio do Rasto Formations (Damiani Pinto et al., 1966).

Among the clay minerals, illite is the dominant mineral followed by chlorite. Mixed-layer illite-montmorillonite occurs in minor amounts. Montmorillonite is present in two samples. As in the Corumbataí Formation, montmorillonite and chlorite do not occur 
associated within the studied samples. Thin beds of an aluminous dioctahedric smectite from sediments attributed to this formation, were described by Pintaúde and Formoso (1972) in Aceguá, Rio Grande do Sul. Its origin is doubtful, having been interpreted either as in situ altered volcanic material - hypothesis considered to be the most reasonable, although no source area be known - or from granulometric segregation in standing, quiet waters.

CLAY MINERALS OF THE RIO DO RASTO GROUP 104 core samples from 23 wells represent this group in this study. No samples came from the São Paulo State. According to Sanford and Lange (1960), the group consists of two formations: the lower one is called the Serrinha, and the upper one, the Morro Pelado Formation. The Serrinha Formation is composed of fine sandstones, siltstones and shales, mainly of greenish gray color, with thin beds of limestone and chert in the lower part; it was probably deposited in transitional environment, passing from shallow marine to brackish and continental. The Morro Pelado Formation consists of red and variegated sandstones, siltstones and shales, and is characterized by the lenticularity of the beds; it is supposed to be deposited in continental fluvial environment. In this work, even where it was possible, no attempt was made to separate these two units. In the western part of the Rio Grande do Sul State, it was used the name Rio do Rasto Formation given to the section by Damiani Pinto et al. (1966). Greatest thickness was recorded in the Marcelino Ramos well (2-MR-I-RS) with 783 m.

Illite and montmorillonite are the most important clay minerals. Mixed-layer illite-montmorillonite and chlorite are subordinate. Kaolinite is very rare. Corrensite occurs in the lower part of the section, probably related to the transitional environment associated with limestone and calcareous shale beds. Montmorillonite becomes more abundant toward the uppermost layers as well as in the overlying Botucatu Formation.

The authors believe that montmorillonite was being formed in the weathering mantles and in the soils, and transported to the depositional basins. Climate was tending to semiarid and arid. Poorly drained soils should have inhibited more intense alterations, leading to the formation of montmorillonite instead of kaolinite, and oxidizing environments favored the formation of red beds (Chukrov, 1973).

CLAY MINERALS OF THE BOTUCATU FORMATION This study comprises 32 core samples from 10 wells belonging to this formation. Lithologically, it is mainly made up of reddish to yellowish, fine to medium, cross-stratified sandstones. Subordinately, there occur some claystones and argillaceous sandstones. The Santa Maria and Pirambóia Formations are also included in this topic. The former one is restricted to the Rio Grande do Sul State and consists of red fine sandstones and claystones, with some calcareous concretions. The latter one occurs in the São Paulo State. The Botucatu Sandstones are attributed to an eolian deposition, while the Santa Maria and Pirambóia are supposedly deposited in fluvial and/or lacustrine environments (Sanford and Lange, 1960). Greatest composite thickness was recorded at the Alegrete well (2-AL-1-RS) with $843 \mathrm{~m}$.

Montmorillonite is the dominant clay mineral. It is present in all but 4 of the studied samples, elsewhere from the Rio Grande do Sul to the São Paulo State. Fig. 10 illustrates the X-ray diffraction patterns of montmorillonite. Other clay minerals are illite, abundant in only one well, chlorite, and very rare mixed-layers. Kaolinite occurs only in the Alegrete well.

Aridity tends to inhibit the formation of kaolinite and mixed-layers in favor of montmorillonite. Based on the widespread occurrence of montmorillonite in this formation, it is believed that the probability of its origin from surficial weathering is greater than being 


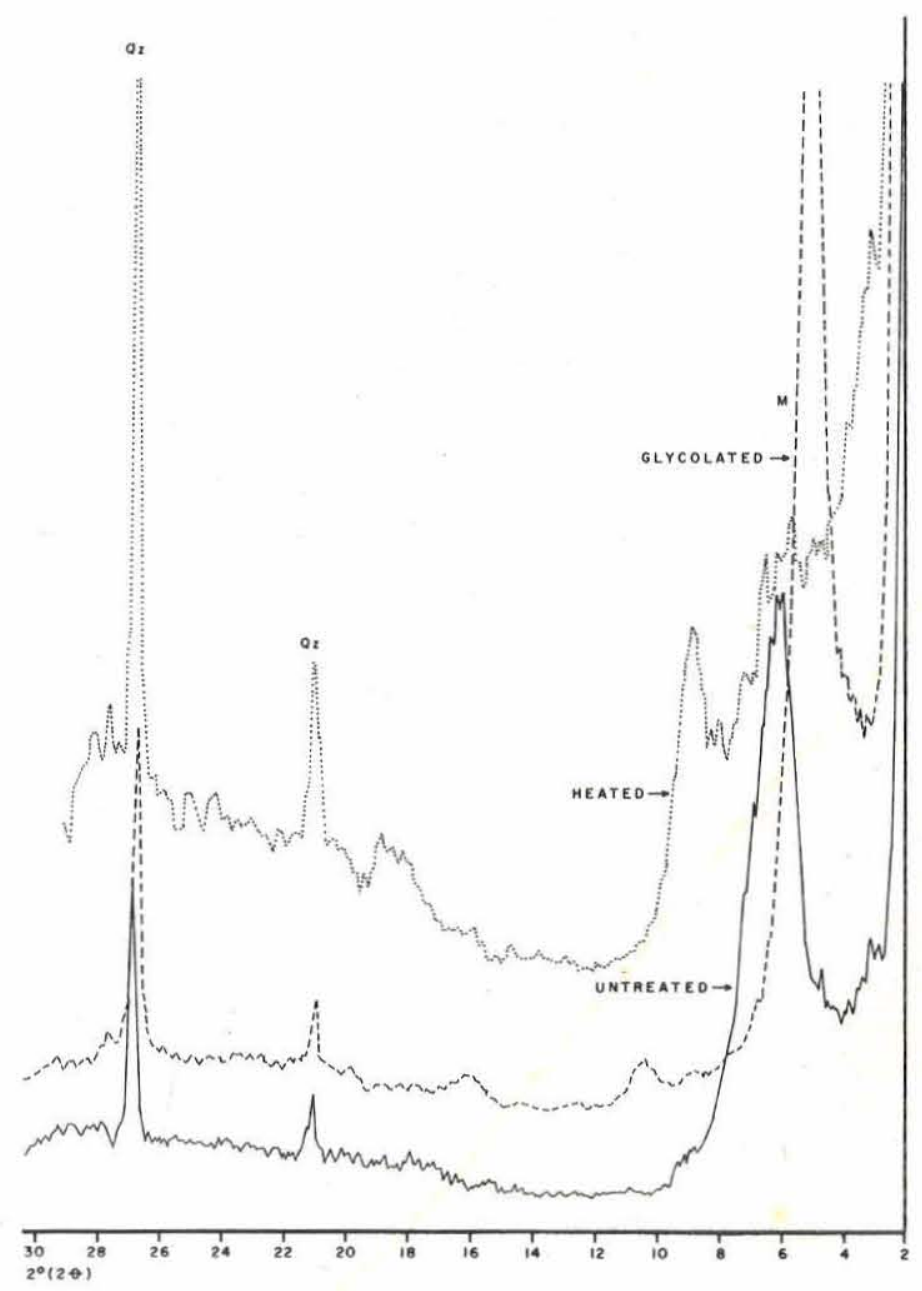

Figure 10 - X-ray diffractometer curves of sample 527, core 6, depth 528,0 m, Botucatu Formation, 2-AL-1-RS well, illustrating montmorillonite $(\mathrm{M})$ patterns. Quartz $(\mathrm{Qz})$ is also present

originated from a source area rich in volcanic materials, although this hypothesis could not be entirely excluded.

Relationship between clay minerais and diagenetic processes Since deposition until their transition to metamorphic rocks, sediments experiment post-depositional changes, understood as diagenesis, by occidental authors. The russians reserve this term to the pre-lithification changes while the post-lithification processes are called epigenesis. The term diagenesis was introduced by Von Gumbel in 1868, and epigenesis by Pustovalov in 1940. Larssen and Chillingar (1967), and Dunoyer de Segonzac (1968) have presented a complete revision about the subject. The terminology related to diagenesis and its frontier limits with metamorphism were discussed by Correns (1950), Sujkowski (1958), Kubler (1964) Dunoyer de Segonzac (1970), Kossovskaya and Shutov (1970), and Pettijohn, Potter and Siever (1973). 
Under diagenetic processes, induced by the thermodinamical variables, pressure and temperature, besides the chemical changes in the connate waters, the original composition of the clay minerals may be somewhat modified, and the extension of the modifications will depend on the degree of the involved processes. Unstable minerals may disappear and authigenic minerals may be formed, while most of the clays may be transformed, either by aggradation or degradation, depending on the available ions. In the pre-lithification stage, the clay minerals are stable; some may be aggraded by adsorption of $\mathrm{Mg}^{++}, \mathrm{K}^{+}$and $\mathrm{Na}^{+}$, as for instances, some mixed-layers, and a few may be neoformed, like montmorillonite. In the intermediate phase, there is an expulsion of great part of connate waters and the interstitial circulation leads to mineral transformations, such as illitization of montmorillonite. In the final stage, under temperatures greater than $100^{\circ} \mathrm{C}$ and increasing pressures besides loss of porosity, minerals like montmorillonite and irregular mixed-layers disappear and kaolinite is recrystallized into dickite. In the transitional zone preceding the metamorphism, the temperatures may reach $200{ }^{\circ} \mathrm{C}$ and the observed clay minerals are almost exclusively illite and chlorite.

Weaver (1960), Kubler (1964), and Dunoyer de Segonzac, Ferrero and Kubler (1968) have developed methods for determining the degree of metamorphism from the crystallinity of illite. In this work the authors have utilized the index proposed by Kubler, which varies inversely to the crystallinity of illite.

Practical aspects of diagenetic studies in the field of petroleum geology have been presented by Kossovskaya and Shutov (1970), Prozorovich (1970), Smoot and Narain (1960), and Kulbicki and Millot (1960).

In the present study, the authors have attempted to use the clay mineral data, both from a detrital or diagenetic origin, as an auxiliary tool in reconstructing the depositional environments. In some formations, environment has been inferred from fossils, lithology and sedimentary structures, and it has been found that clay mineral data agree, generally speaking, with some previous investigations. Lateral variations due to diagenetic changes must be understood and may be useful in the environmental investigation.

CONSIDERATIONS ON CORRENSITE Corrensite is a term coined by Lippman in 1954 to designate a regular interstratification of a normal chlorite layer and another expansive layer. Corrensite would be formed by fixation of $\mathrm{Mg}^{++}$ions inside the degraded mineral layers, in a medium containing an excess of magnesium (Lucas, 1962). Aggradation would occur during sedimentation (Dunoyer de Segonzac, 1970), or latter during diagenesis; the minerals should be in equilibrium with the depositional or diagenetic medium, immediately after sedimentation (Peterson, 1962). Degraded clay minerals, derived from the continents are unstable ion-deficient particles of general small size. The aggradation mechanism would depend on the alteration degree of the inherited particles, and on the nature and concentration of the solutions in which the degraded particles are put in contact with. Thus, variations in $\mathrm{K}^{+}$and $\mathrm{Mg}^{++}$concentrations would affect diagenesis in marine environments ranging from oxidizing to reducing conditions (Grim, 1968). As freshwater contains only small quantities of magnesium, the formation of corrensite implies higher concentration of ions in solution, either in the marine waters during deposition or in the connate waters, after expulsion by compaction and burial, during diagenesis. Sudo, Hayashi, and Shimoda (1962) have reported the occurrence of mixed-layer clay minerals, in areas subjected to different conditions of the chemical environment or in transitional areas between two different chemical environments. Regular mixed-layer clay minerals have not been related in surficial recent sediments or in metamorphic facies, and accordingly, they have been interpreted by Kubler (1973) as indicators 
of diagenetic zones. Based on the major types of occurrence, that author concludes that corrensite is formed under normal diagenetic conditions at temperatures from $90^{\circ} \mathrm{C}$ to $100^{\circ} \mathrm{C}$ in the association with evaporitic and carbonatic facies. The corrensite key-beds in the Sahara are still at a temperature around $90^{\circ} \mathrm{C}$ at depths of $3,000 \mathrm{~m}$. Corrensite has been found even at depths of $5,000 \mathrm{~m}$ and at a temperature of $148^{\circ} \mathrm{C}$ in the Niigata oil field in Japan (Iijima and Utada, 1971). Under deep diagenesis, corrensite would be transformed into chlorite (Millot, 1964).

In the Paraná Basin, corrensite was found widespreadly associated with the oolitic limestone zones of the upper part of the Teresina Formation. It was also reported in the overlying transitional sediments of the Serrinha Formation and, less important, in a few occurrences in the underlying Serra Alta and Irati Formations. The most characteristic well section is the Lagoa Vermelha well (2-LV-1-RS). Corrensite was verified in the basin at depths varying from around 100 to $2,340 \mathrm{~m}$. The corrensite horizons associated with the Teresina oolitic limestones constitute good key-beds. Sedimentation is at tributed to a subaqueous probably marine environment, necessary for a high magnesium concentration. Deposition was probably accomplished under conditions of a wide very shallow stable epicontinental platform, as evidenced by persistence of the layers over hundreds of kilometers, without large lithologic, facies or formation thickness variations.

Relationship between hydrocarbon occurrence and clay minerais Several authors have attempted to establish the relationship between the origin, migration and production of petroleum and the clay minerals. Grim (1947) points out their affinity with organic compounds, either by catalytic effects or by adsorption properties. This affinity is greater among montmorillonites than kaolinites, and greater among expansive mixed-layers than non-expansive ones. Weaver (1960) analyzed the statistical relationship between hydrocarbon production and expansive clay minerals in more than 20,000 samples from the major United States basins as shown in Fig. 11. The greater the amount of montmorillonite and of expansive mixed-layers, the greater the oil production, as for instances, the Tertiary sediments; most of the producing intervals of Cretaceous; the Chester Formation of Illinois Basin; the Permian formations of Texas and Oklahoma; etc. Generally, in a basin, rocks with higher amounts of expansive clay minerals are better producing intervals than other formations in the same areas.

Bhattacharya $(1962,1969)$ admits that expansive clay minerals are necessary for hydrocarbon occurrence and points out the relationship between montmorillonites and hydrocarbon origin. Smoot and Kedar (1960) determined the clay mineral compositions of approximately 70 samples of oil-bearing and non-oil bearing sandstones from the Mississipian Chester Formation of the Illinois Basin. The oil bearing sandstones are richer in kaolinite and mixed-layer illite-montmorillonite and inversely poorer in illite and chlorite than the non-oil bearing sandstones. Differences were thought to be, at least partly, a function of the presence or absence of oil. Also, Smoot (1960a), studying five sandstone samples with varying permeabilities from a single core from the Chester Formation, found that with decreasing permeability there was a relative increase in illite and chlorite accompanied by a decrease in kaolinite, montmorillonite and mixed-layer clay minerals. According to Sarkisyan (1967), the clay minerals play an important role in the formation of oil and gas deposits, as they are directly related to the process of bitumen formation and to the properties of reservoir and cap rocks. Expansive minerals, as montmorillonite, mixed-layer illite-montmorillonite and degraded illites, exhibit catalyctic activity in the process of oil generation and adsorb hydrocarbons derived from the transformation of dispersed organic matter. The relationship between oil production and clay minerals has been dis- 


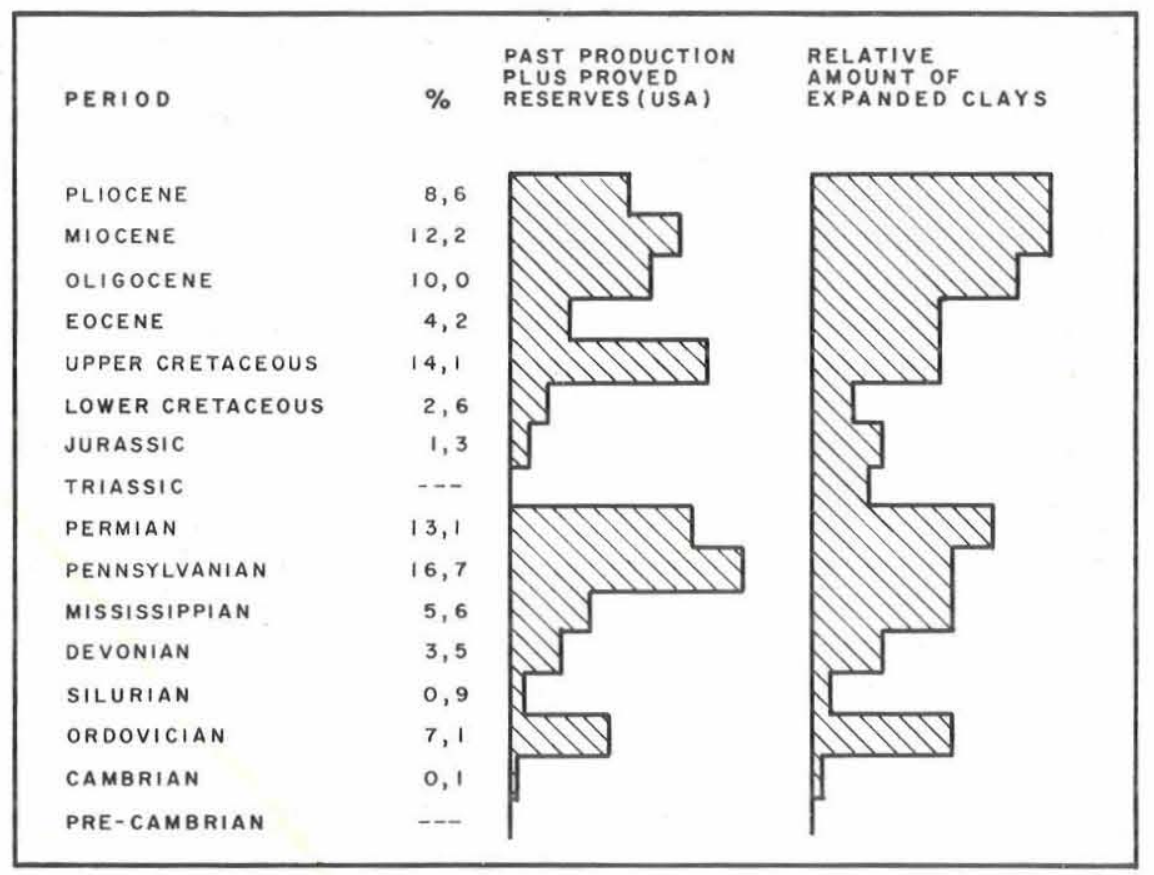

Figure 11 - Relation of oil production and age with relative amount of expansive clay minerals (After Weaver, 1960)

cussed by Grim (1947), Bhattacharya (1969), and Sarkisyan (1967). Drilling muds, whose compositions differ from those of the formation waters, may cause changes either in the relative position of the clay minerals in regard to the other detrital minerals, such as quartz and feldspar, or in the expansive clay minerals, clogging, in both cases, the pores. Powers (1967) and Burst (1969) have attributed an important role to the clay mineral diagenesis in petroleum migration, especially to the illitization of montmorillonite under burial and compaction, with expulsion of great amounts of water.

In this study of the Paraná Basin, it has been observed a greater development of mixed-layer illite-montmorillonite in the Rio Bonito Formation. The best and most numerous hydrocarbon shows throughout the column have been recorded in this formation. In several wells drilled in the Santa Catarina State, some oil and/or gas have been produced from the Rio Bonito sandstones. Thus, this finding agrees with the universal relationship observed between those clay minerals and the presence of petroleum.

CONCLUSIONS The following main conclusions may be drawn from the study of the observed clay mineral lateral and vertical variations:

1. The clay minerals present in the study area are mainly inherited from the source areas, although in some cases, diagenetic processes have been inferred from the clay mineral composition;

2. Dominant minerals are illite, chlorite and mixed-layer illite-montmorillonite. Montmorillonite, kaolinite and corrensite are subordinate;

3. Diagenetic changes have led to the recrystallization or neoformation of some illite, kaolinite and corrensite; 
4. Presence of well-crystallized illite with relative absence of mixed layer illite-montmorillonite, besides occurrence of pyrophyllite, can be interpreted as evidence of diagenetic processes in the older Furnas and Ponta Grossa Formations;

5. Illite and chlorite are highly dominant in the Itararé Group and reflect, in the authors' opinion, little alteration in the source area due to climatic conditions during deposition and/or high relief. Kubler's index values are low because of these reasons;

6. Mixed-layer illite-montmorillonite is the characteristic mineral of the Rio Bonito Formation, reflecting the more intensive alterations in the source areas due to less rigorous climates or the presence of post-depositional degradational changes;

7. Kaolinite is important in the areas considered to be deltaic or nearshore and in the coal basins of that formation, showing the presence of leaching conditions. Recrystallization of kaolinite was also noted;

8. Corrensite occurs mainly associated with the oolitic limestone zones of the Teresina Formation, suggesting diagenetic processes in marine environment;

9. Montmorillonite is most important in the upper part of the Basin's stratigraphic column, especially in the Botucatu Formation and upper Rio do Rasto Group, denoting typical contribution of source areas under arid or semi-arid climates and non-leaching conditions; 10. Chlorite occurs throughout the column. Expansive chlorite, irregular mixed-layer chlorite-montmorillonite, corrensite and magnesian chlorite were also found, suggesting alteration from degraded chlorites in the former two minerals and diagenesis in the latter ones; and

11. Greater abundance of mixed-layer illite-montmorillonite in the Rio Bonito Formation, in which innumerous shows and non-commercial production of liquid and gaseous hydrocarbons have been reported, is in accordance with the universal relationship verified between these clay minerals and oil occurrence.

AKNOWLEDGEMENTS The authors wish to express their appreciation to Petróleo Brasileiro S.A. - Petrobrás - for cooperation and for permission to publish this paper. Special thanks are due Dr. Francisco Paula de Medeiros, General Superintendent of Exploration and Production Department, Dr. Carlos Walter Marinho Campos, Manager of Exploration Division, and Dr. Álvaro Renato Pontes, Chief of Geological Sector. The authors are also indebted to Universidade Federal do Rio Grande do Sul for technical facilities and to Dr. Cesar Dornelles Willig, former head of X-ray laboratory of Instituto de Geociências da UFRGS.

\section{REFERENCES}

BARBOSA, O., and GOMES, F. A. - 1958 - Pesquisa de petróleo na Bacia do Rio Corumbataí, Est. São Paulo. DNPM, Div. Geol. Min., Bol., 71: 40 pp

BHATTACHARYA, N. - 1962 - Recent advances in clay mineralogy as applied to petroleum industry: Part I - Fundamental generalizations. Jour. Sci. Ind. Res., 21 A (10): 477-483

BHATTACHARYA, N. - 1969 - Clay diagenesis and associated primary migration of petroleum from source rocks. Bull. Oil Natur. Gas Comm., 6(1):38-43

BRADLEY, W. F. - 1954 - X-Ray diffraction criteria of chlorite material. Clays Clay Minerals, Publ., 327: 324-334

BRINDLEY, G. W. - 1961 - Quantitative analysis of clay mixtures, in Brown G. (Editor) The X-Ray identification and crystal structures of clay minerals. Miner. Soc. (Clay Mineral Group) London: 489:516

BRINDLEY, G. W., and ALI, S. Z. - 1950 - Thermal transformation in magnesian chlorites. Acta Cryst., 3: 25-30 
BROWN, G. (Editor) - 1961 - The X-Ray identification and crystal structures of clay minerals. Minerl. Soc. (Clay mineral Group) London, 544 pp.

BURST, J. F. - 1969 - Diagenesis of Gulf Coast clayey sediments and its possible relation to petroleum migration. Amer. Ass. Petrol. Geol. Bull., 53 (1):73-93

CHUKHROV, F. V. - 1973 - On mineralogical and geochemical criteria in the genesis of red beds. Chem. Geol., 12: 67-75

CORREIA DA SILVA, Z. C. - 1973 - On tonstein in the Candiota mine, RS-Brazil. Compt. Rend., 7. ${ }^{\circ}$ Congr. Inter. Geol. Estrat. Carbonífero (Kreseld, 1971), 2: 287-296

CORRENS, C. W. - $1950-$ Zur Geochimie der Diagenese. I. Das Verhalten von $\mathrm{CO}_{3} \mathrm{Ca}$ und $\mathrm{SiO}_{2}$. Geochim. Cosmochim. Acta, 1: 49-59

DAMIANI PINTO, I. (Coordinator) - 1966 - Geology of the State of Rio Grande do Sul Brazil. Publ. Esp. Esc. Geol. UFRGS, 11: 12 pp.

DELANEY, P., and FORMOSO, M. L. L. - 1960 - Ocorrência de uma chamada bentonita em São Gabriel, RS. Esc. Geol. UFRGS, Bol., 2: 13 pp.

DUNOYER DE SEGONZAC, G. - 1968 - The birth and development of the concept of diagenesis (1866-1966). Earth Sci. Rev., 4: 153-201

DUNOYER DE SEGONZAC, G. - 1970 - The transformation of clay minerals during diagenesis, and low grade metamorphism: a review. Sedimentology, Special Issue, Lithification of Clastic Sediments, $15(3 / 4)$ : 281-346

DUNOYER DE SEGONZAC, G., FERRERO, J., and KUBLER, B. - 1968 - Sur la cristallinité de l'illite dans la diagenèse et l'anchimétamorphisme. Sedimentology, 10 (2): 137-143

ESQUEVIN, J. - 1969 - Influence de la composition chimique des illites sur leur cristallinité. Bull. Centre. Rech. Pau, 3: 147-154

FORMOSO, M. L. L. - 1963 - Determinação semiquantitativa de argilominerais por difração de raios $\mathrm{X}$ em sedimentos paleozóicos. Cerâmica, 10 (36): 3-14

FORMOSO, M. L. L. - 1966 - Alguns aspectos geológicos e tecnológicos das principais ocorrências de argilas no Rio Grande do Sul. Cerâmica, 47/48

FORMOSO, M. L. L., and FIGUEIREDO F. ${ }^{\circ}$, P. M. - 1966 - Estudo sedimentológico do Grupo Guatá. Publ. Esp. Esc. Geol. UFRGS, 12: 55 pp.

FORMOSO, M. L. L., and FIGUEIREDO F. ${ }^{\circ}$, P. M. - 1971 - Ocorrência de uma camada de montmorilonita em Biboca, RS. Notice presented to XXV Congresso Brasileiro de Geologia, S. Paulo

GRIFFIN, G. M., and INGRAM, K. L. - 1955 - Clay minerals of the Neuse River Estuary. J. Sediment. Petrology, 25: 194-200

GRIM, R. E. - 1947 - Relation of clay mineralogy to origin and recovery of petroleum. Bull. Amer. Ass. Petrol. Geol. 31 (8): 1491-1 499

GRIM, R. E. - 1968 - Clay Mineralogy, 2nd ed., McGraw-Hill Book Co. N. York, 596 pp.

IIJIMA, A., and UTADA, M. - 1971 - Present-day zeolitic diagenesis of the Neogene geosynclinal deposits in the Niigata Oil Field, Japan. Adv. Chem, Ser., 101, Molec. Sieve Zeolit. I: 342-349

JOHNS, W. D., GRIM, R. E., and BRADLEY, W. F. - 1954 - Quantitative estimation of clay minerals by diffraction methods. J. Sediment. Petrology, 24 (4): 242-251

JUNG, J. - 1954 - Les illites du Bassin oligocène Salins (Cantal). Bull. Soc. Franc. Min. Crist. (77): 1 231-1 249

KELLER, W. D. - 1956 - Clay minerals as influenced by environments of their formation Amer. Ass. Petrol. Geol. Bull., 40 (11): 2689-2 710

KUBLER, B. - 1964 - Les argiles, indicateurs de métamorphisme. Rev. Inst. Franc. Petrol. XIX (10): $1093-1112$

KUBLER, B. - 1973 - La Corrensite, indicateur possible du milieux de sédimentation et du degré de transformation d'un sédiment. Bull. Centre Rech. Pau, 7 (2): 543-556

KOSSOVSKAYA, A. G., and SHUTOV, V. D. - 1970 - Main aspects of the epigenesis problem. Sedimentology, Special Issue, Lithification of clastic sediments, 15 (1/2): 11-40

KULBICKI, G., and MILLOT, G. - 1960 - L'évolution de la fraction argileuse des grés pétroliers cambro-ordoviciens du Sahara central. Bull. Serv. Carte Géol. Als Jor., 13: 147-156 
LARSSEN, G., and CHILlingAR, G. V. (Editors) - 1967 - Diagenesis in sediments. Developments in Sedimentology n. 8: Elsevier Publishing Co., N. York, 551 pp.

LUCAS, J. - 1962 - La transformation des minéraux argileux dans la sédimentation. Étude sur les argiles du Trias, Mém. Serv. Carte Géol. Als. Lorr., 23: 202 pp.

LUCAS, J., CAMEZ, Th., and MILLOT, G. - 1959 - Détermination pratique aux rayons X des minéraux argileux simples et interstratifiés. Bull. Serv. Carte Geol. Als. Lorr, 12, (2): 21-31

LUCAS, J., and JEHL, G. - 1961 - Étude de l'action de la chaleur sur la chlorite et la kaolinite par diffraction des rayons X. Application à la distinction de ces minéraux. Bull. Serv. Carte Géol. Als. Lorr., EG., 4: 159-171

LUDWIG, G., and RAMOS, A. N. - 1965 - Estudo faciológico das formações Iapó, Furnas e Ponta Grossa do Paleozóico Inferior da Bacia do Paraná, Petrobrás/DESUL (unpublished)

MILLOT, G. - 1952 - Prospecting for useful clays in relation with their conditions of genesis: Symposium-Problems of Clay and Laterite Genesis, A.I.M.E.: 107-114

MILlOT, G. - 1964 - Géologie des Argiles, Masson et Cie., Ed. Paris, 499 pp.

MILNE, I. H., and EARLEY, J. W. - 1958 - Effect of source and environment on clay minerals. Amer. Ass. Petrol. Geol. Bull., 42 (2): 328-338

NEVES, L. E. - 1973 - Dados preliminares para o estudo do potencial gerador dos folhelhos da Bacia do Paraná (1. ${ }^{\circ}$ Relatório Parcial): Centro de Pesquisas e Desenvolvimento, Petrobrás (unpublished)

NORTHFlEET, A.A., MEDEIROS, R. A., and MUHLMANN, H. - 1969 - Reavaliação dos dados geológicos da Bacia do Paraná. Bol. Tec. Petr., 12 (3): 291-346

PARHAM, W. E. - 1964 - Lateral clay mineral variations in certain Pennsylvanian underclays. Clays Clay Minerals. Proc. of the 12th Nat. Conf. (1963): 581-602

PARHAM, W. E. - 1966 - Lateral variations of clay minerals assemblages in modern and ancient sediments. Proc. of the Internat. Clay Conference, 1966, Jerusalem, Israel, 1: 135-145

PETERSON, M.N.A. - 1962 - The mineralogy and petrology of Upper Mississipian carbonate rocks of the Cumberland Plateau in Tennessee. Jour. Geol., 70: 1-31

PETtiJOhn, F. J., POTTER, P. E., and SIEVER, R. - 1973 - Sand and Sandstones. Springer Verlag, N. York, 618 pp.

PINTAÚDE, D. A., and FORMOSO, M. L. L. - 1972 - Ocorrência de argila montmorilonítica em Aceguá, RS. Inst. Tec. Rio Grande do Sul, Bol. 57

POWERS, M. P. - 1967 - Fluid-release mechanism in compacting mudrocks and their importance in oil exploration. Amer. Ass. Petrol. Geol. Bull., 51 (7): 1240-1 254

PROZOROVICH, G. E. - 1970 - Determination of the time of oil and gas accumulation by epigenesis studies. Sedimentology, Special Issue. Lithification of clastic sediments 15 (1/2): 41-52

PRYOR, W. A., and GLASS, H. D. - 1961 - Createceous - Tertiary clay-mineralogy of the Upper Mississippi Embayment. J. Sediment. Petrology, 31: 38-51

RAMOS, A. N. - 1967 - Análise estratigráfica da Formação Rio Bonito. Bol. Tec. Petr., 10 (3/4): $357-407$

RAMOS, A. N. - 1970a - Resultados de análises difratométricas da fração argilosa de testemunhos de poços da Bacia Sedimentar do Paraná. Bol. Tec. Petr. 13 (1/3): 15-25

RAMOS, A. N. - 1970b - Aspectos paleoestruturais da Bacia do Paraná e sua influência na sedimentação. Bol. Tec. Petr., 13 (3-4): 85-93

SANFORD, R. M., and LANGE, F. W. - 1960 - Basin-study approach to oil evolution of Paraná miogeosyncline, South Brazil. Amer. Ass. Petrol. Geol. Bull., 44 (8): 1 316-1 370

SARKYSIAN, S. G. - 1967 - Clay minerals and their significance in the geology of oil and gas. Inst. IUGS et AL. Clay conf. Proc., 2: 281-292

SCHNEIDER, R. L., MUHLMANN, H., TOMMASI, E., MEDEIROS, R. A., DAEMON, R. F., and NOGUEIRA, A. H. F. A. - 1974 - Revisão estratigráfica da Bacia do Paraná. Annals of the XXVIII Congr. Bras. Geol., Porto Alegre (in press)

SHOVER, E. F. - 1964 - Clay mineral environmental relationships in Cisco (U. Penn) clays and shales, North Central Texas. Clays Clay Minerals, Proc. of the 12th Nat. Conf. (1963): $431-443$ 
SMOOT, T. W. - 1960a - Clay mineralogy of pre-Pennsylvanian sandstones and shales of the Illinois Basin, part I - Relation of permeability to clay mineral suites. Ill. State Geol. Surv. Cir., 286: 19 pp.

SMOOT, T. W. - 1960b - Clay mineralogy of pre-Pennsylvanian Sandstones and Shales of the Illinois Basin, part III - Clay minerals of various facies of sone Chester formations. Ill. State Geol. Surv. Circ., 293: 19 pp

SMOOT, T. W., and KEDAR, N. - 1960 - Clay mineralogy of pre-Pennsylvanian sandstones and shales of the Illinois Basin, part II - Relation between clay mineral suites of oil bearing and non-oil bearing rocks. Ill. State Geol. Surv. Cir., 287: 14 pp.

SNPA - Soc. Nat. Pétr. Aquitaine - 1973 - Étude sédimentologique et géochimique preliminaire de 25 sondages du bassin du Paraná (Brésil), Note R/GEO n. ${ }^{\circ}$ 184/73 (unpublished)

SUDO, T., HAYASHI, H., and SHIMODA, S. - 1962 - Mineralogical problems of intermediate clay minerals. Clays Clay Min. 9th Nat. Conf. 1960: 378-392

SUJKOWSKI, Zb. L. - 1958 - Diagenesis. Amer. Ass. Petrol. Geol. Bull, 42 (11): 2692-2 717

THOMAS F. ${ }^{\circ}$, A., and MEDEIROS, R.A. - 1972 - Projeto Rio Bonito, Fase II, Petrobrás/ DESUL (unpublished)

WEAVER, C. E. - 1958 - Geologic Interpretation of argillaceous sediments, Part I - Origin and significance of minerals in sedimentary rocks. Amer. Ass. Petrol. Geol. Bull. 2 (2): 254-271

WEAVER, C. E. - 1958 - Geologic interpretation of argillaceous sediments, Part II - States. Amer. Ass. Petrol. Geol. Bull., 42 (2): 272-309

WEAVER, C. E. - 1960 - Possible uses of clay minerals in search for oil. Amer. Ass. Petrol. Geol. Bull., 44 (9): 1 505-1 518

WEAVER, C. E. - 1967 - The significance of clay minerals in sediments, in: Nagy, B. e Colombo, U. (Editors), Fundamental aspects of petroleum geochemistry, Elsevier Publish. Co., N. York, Amsterdam: 37-75

WILLIG, C. D., and FORMOSO, M. L. L. - 1971 - A espectrofotometria de absorção infravermelha da região OH-stretching de esmectitas do Gondwana do Rio Grande do Sul. Notice presented to XXV Congresso Brasileiro de Geologia, São Paulo 